\title{
Urban Seismology in the Taipei Metropolitan Area: Review and Prospective
}

\author{
Jeen-Hwa Wang ${ }^{1, *}$ \\ ${ }^{1}$ Institute of Earth Sciences, Academia Sinica, Taipei, Taiwan, ROC
}

Received 15 November 2006, accepted 9 July 2007

\begin{abstract}
A strong collision between the Eurasian and Philippine Sea Plates causes high seismicity in the Taiwan region. A substantial number of cities and large towns exist on thick sediments in western Taiwan. Larger-magnitude inland earthquakes, for example the 1999 Chi-Chi earthquake, can cause serious damage in urban areas. Consequently, urban seismology is of great interest to the local seismological community. The Taipei Metropolitan Area (TMA) is the political, economic, and cultural center of Taiwan. It is situated over a region where the Philippine Sea plate subducts the Eurasian plate. Although seismicity in the TMA is lower than other areas of Taiwan, earthquakes still occur. Seismic risk mitigation is of grave concern in the TMA because of its high population, number of tall buildings, mass rapid transit system, and two nearby nuclear power plants. In this article, procedures for seismic risk mitigation, previous studies, core issues for future research and related topics are described and reviewed.
\end{abstract}

Key words: Seismic risk, Seismic hazard, Urban seismology

Citation: Wang, J. H., 2008: Urban seismology in the Taipei Metropolitan Area: Review and prospective. Terr. Atmos. Ocean. Sci., 19, 213-233, doi: 10.3319/TAO.2008.19.3.213(T)

\section{INTRODUCTION}

Earthquakes are a natural phenomenon releasing stress accumulated in the Earth's crust due to plate tectonics. Most earthquakes happen in the collision zone between two plates, but some occur in so-called stable areas, i.e., the central parts of continents and large sea floors. Generally, earthquakes occurring under the sea or in places of few inhabitants cause little or no damage to people or property except in the case of tsunamis such as the devastating 2004 Sumatra-Andaman. Unfortunately, a large number of mega-cities have been built over or near active faults where earthquakes of larger magnitude (for example, the 1906 San Francisco earthquake, 1923 Kwanto earthquake, 1935 Hsintsu-Taichung earthquake, 1976 Tangshan earthquake, 1994 Northridge earthquake, 1995 Kobe earthquake, 1999 Chi-Chi earthquake, and 2005 Pakistan earthquake) can occur, causing severe damage. Dense population levels in such cities leads to the construction of ever higher buildings, water reservoirs, bridges, railways and other transit systems; all of which are vulnerable to damage from large

\footnotetext{
* Corresponding author

E-mail:jhwang@earth.sinica.edu.tw
}

earthquakes. From a comparison between earthquakes and urban growth, Bilham (1988) concluded that earthquake risk is especially high in the cities of developing countries, because of poor construction methods and low collaboration between seismologists and urban planners. Hence, studies of mitigating seismic risk in urban areas (i.e., urban seismology) are important not only for developing countries but also for developed ones.

Possible seismic hazards caused by earthquakes are: (1) surficial ruptures, liquefaction, landslides, and tsunamis; (2) collapse or damage of civil structures and buildings (e.g., houses, bridges, water dams etc.); (3) damage of transportation systems; (4) damage to pipeline systems (e.g., gas, water, electricity, communication etc.); (5) fire; and (6) flood due to dam wall collapses. Such devastation could result in many human and animal casualties as well as economic loss. In addition large temblors can compound the extent of a catastrophe via affecting the efficiency and effectiveness of emergency services by destroying and/or disrupting police, fire and medical services and facilities. Other possible disasters in mountainous regions such as Taiwan are landslides caused by ground movement in conjunction with heavy rains affecting the stability of surface soils. 
Whilst undoubtedly earthquakes cause a great deal of tragedy and devastation in urban regions, their unforgiving nature forces those of us that live within their reach to better understand them and our own reactions to them. We need to appreciate that we can contribute to better outcomes post a catastrophic earthquake by addressing issues such as community response and emergency services and that we can also mitigate earthquake damage through better understanding of urban seismology and how it pertains to construction and community education.

The Taipei Metropolitan Area (TMA) (Fig. 1) is the political, economic, and cultural center of Taiwan. Regionally the Philippine Sea plate and the Eurasian plate are colliding. Under the northern region of Taiwan, where the TMA is located, the Philippine Sea plate, which moves northwestward at a speed of about $8 \mathrm{~cm} \mathrm{yr}^{-1}$, is subducting the Eurasian plate (Seno 1977; Tsai et al. 1977; Wu 1978; Lin 2002). This collision causes high seismicity in the Taiwan region (Wang 1988b, 1998). Historically, there have been many destructive inland earthquakes. In addition to Taipei, a substantial number of cities and large towns, including the two mega-cities of Taichung and Kaoshung, are situated on thick sediments in western Taiwan. These highly populated cities are regional centers of culture, economics, and politics.
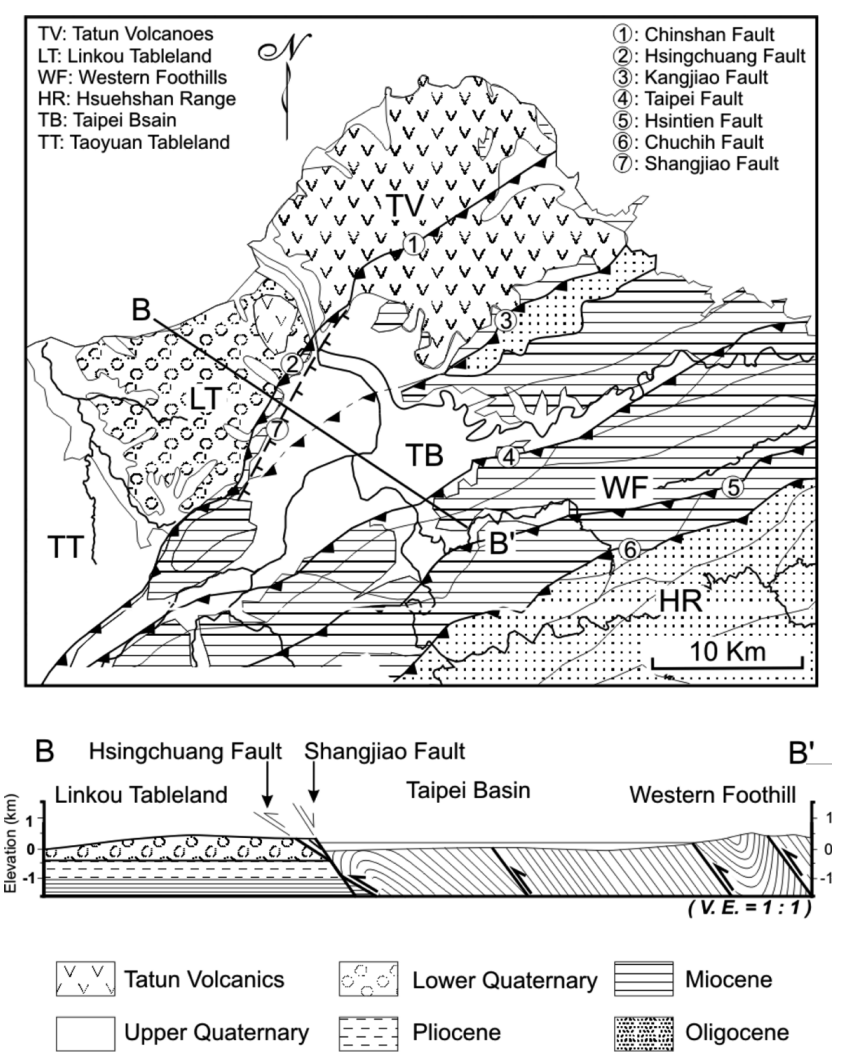

Fig. 1. Upper: geology map of the Taipei metropolitan area and surroundings (after Teng et al. 2001); Lower: geological profile along Line BB' shown in the upper diagram.
Large earthquakes, for example the $1935 \mathrm{M}_{\mathrm{s}} 7.3$ HsintsuTaichung earthquake (cf. Wang 1998) and the $1999 \mathrm{M}_{\mathrm{s}} 7.6$ Chi-Chi earthquake (Ma et al. 1999; Shin and Teng 2001) caused serious damage in many cities and towns, especially those nearer the earthquake faults. In recent years, a highspeed transportation system joining northern and southern Taiwan has been constructed. This system is also located along the west coast of Taiwan, where seismicity is high and the site amplification is strong due to thick sediments. As for the TMA, its population has increased remarkably in recent decades and so too has the number of high rise buildings and extent of city infrastructure from new roads and bridges to the construction of a raised and subterranean rapid transit system; in addition, there are two nearby nuclear power stations. Clearly, there is a need for seismic risk mitigation through out Taiwan and especially in the TMA. Consequently, urban seismology is of great interest to seismologists and should be equally so for policy makers and urban planners.

For Taiwan, prior to 1897 the earthquake record is totally dependent upon historical documents (Hsu 1983a); however, in 1897, the Japanese started seismological monitoring at Taihoku (Taipei) Meteorological Observatory and continued to install seismic stations around the island. A history of the construction of the seismic network during the Japanese occupation can be found in Hsu (1961), Miyamura (1985), and Shin and Chang (2005). By 1935, Japanese seismologists had constructed 17 stations, each equipped with three-component low-gain displacement seismometers. In addition, old-fashioned accelerometers were also installed at some stations. For all stations, seismograms were recorded in analog form. After the Second World War, this seismic network was operated by the Taiwan Weather Bureau (now the Central Weather Bureau, CWB). A detailed description about seismographs and the operation of the network can be found in Li (1983). Although instrumentally-recorded seismograms have been available since 1897 , numerous early seismograms were lost. Since 1953, the CWB has published a bulletin of four volumes annually reporting earthquake data including phases and arrival times.

From 1973 to 1992, the Taiwan Telemetered Seismographic Network (TTSN), sponsored by the National Science Council (NSC), was operated by the Institute of Earth Sciences (IES), Academia Sinica. This network consists of 24 stations, each equipped with vertical high-gain analog velocity seismometers. A detailed description of this network can be seen in Wang (1989). After 1991, the Taiwan Seismic Network (TSN) operated by the CWB was upgraded with many new stations being constructed and merged with the TTSN (1992). A detailed description of the TSN can be found in Shin (1992) and Shin and Chang (2005). At present, the TSN is composed of 72 stations, each equipped with three-component, digital velocity seismometers. Seismograms are recorded in both high- and low-gain forms. 
This network provides high-quality digital earthquake data. Since 1990, an island-wide strong-motion seismic array (TSMIP) of more than 1000 stations in Taiwan has been operated by the CWB (Shin 1993; Kuo et al. 1995; Liu et al. 1999; Shin and Chang 2005). The density of stations, including free-field and building-located stations, of the TSMIP is high in the TMA (Fig. 2). High-quality digital seismic data recorded by the array are available for seismological research and earthquake engineering applications. From 1994 to 2000, under the support of the Central Geological Survey (CGS) a down-hole array consisting of seven stations was operated by the IES. For a variety of reasons four of these stations are now closed. After 2002, this array (Fig. 2) was transferred from the CGS to the IES, and several new stations have been constructed under a project known as SAFE-Taipei (Wang 2006). An example of accelerograms recorded at several surficial stations of the downhole array is depicted in Fig. 3. Figure 4 shows verticalcomponent accelerations recorded at different depths at a down-hole station.

As mentioned above, it is clear that the TMA for a great many reasons constitutes a superior location for urban seismology research. Studies of urban seismology have been conducted by various agencies over a long period of time with valuable results being obtained. Nevertheless, these results are insufficient for seismic risk mitigation purposes. Quite simply, more research is required in the TMA. Of course, much of the knowledge garnered from such research would be applicable in other areas of Taiwan and urban regions around the world. In order to promote urban seismology in the TMA, a three-year project (called SAFETaipei) sponsored by Academia Sinica was launched by the IES in 2005 (Wang 2006). This project could seed a larger program pertaining to urban seismology Taiwan-wide in the near future. In addition, urban seismology is one of the focal points of the newly constructed Taiwan Earthquake Research Center, NSC. In this work, seismic risk, its mitigation, major and related issues relating to such research and field surveys as well as previous studies will be reviewed and described.

\section{SEISMIC RISK}

\subsection{Concept}

Accurate earthquake prediction is, of course, the best way to prevent seismic risk. It is a dream not only of earthquake scientists but also the public. Presently, it is still very difficult to predict an impending earthquake. Until earthquakes can be successfully predicted, the most effective means of mitigating the effects of devastating earthquakes is to have a comprehensive understanding of seismic risk. Seismic risk (SR), which represents probable loss during an earthquake, is controlled by four factors, i.e., seismic hazard $(\mathrm{H})$, exposure $(\mathrm{E})$, fragility $(\mathrm{F})$, and resiliency $(\mathrm{R})$; that is:

$\mathrm{SR}=\mathrm{H} \times \mathrm{E} \times \mathrm{F} / \mathrm{R}$

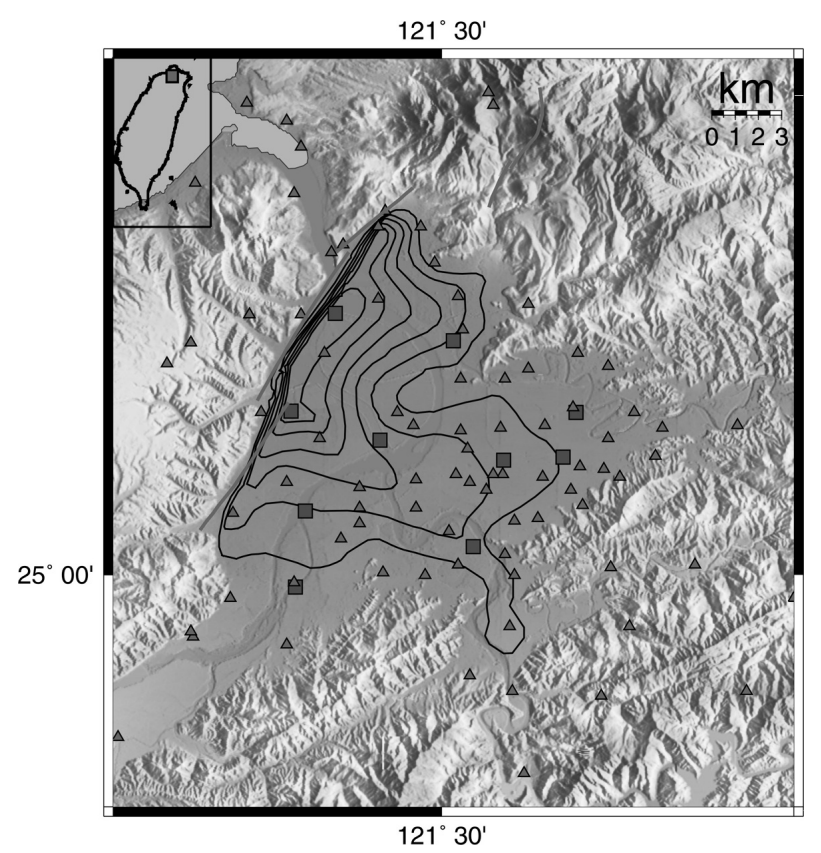

Fig. 2. Strong-motion array in the Taipei metropolitan area: Solid triangles and solid squares show sites of the CWB's free-field strong stations and the IES's borehole stations, respectively. In addition, the contours display the thicknesses of the Taipei Basin.

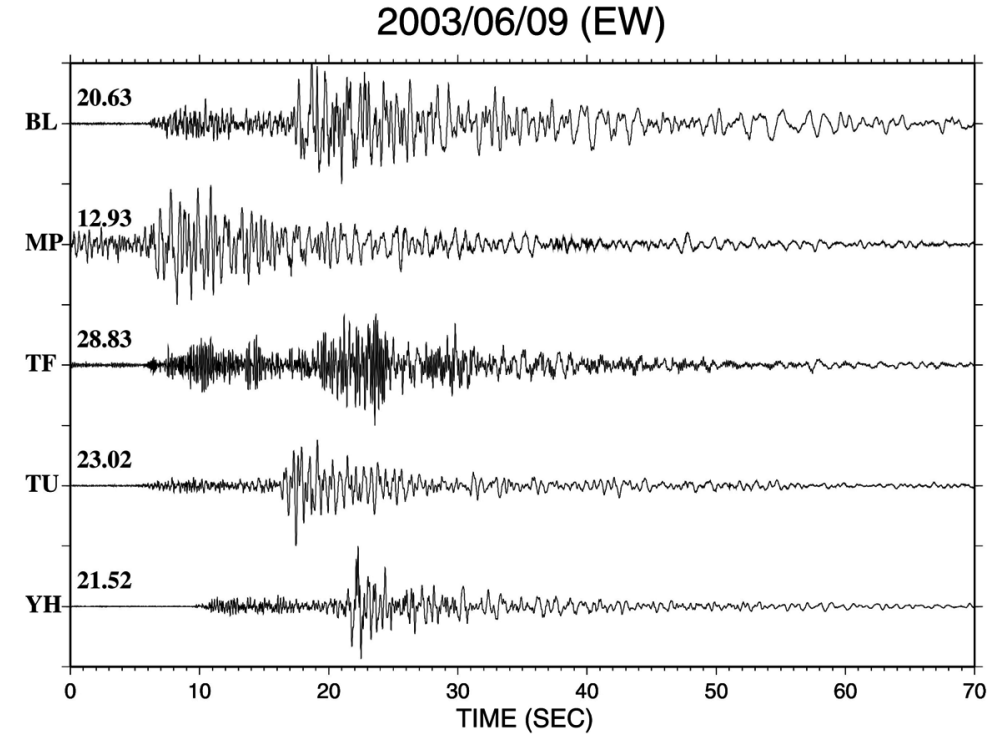

Fig. 3. An example to show the EW-component accelerations of an earthquake of 9 June 2003 ( $\mathrm{M}=5.7$; epicenter: $24^{\circ} 22.22^{\prime} \mathrm{N}, 122^{\circ} 1.40^{\prime} \mathrm{E}$; focal depth: $23.2 \mathrm{~km}$ ) recorded at several free-field seismic stations BL, MP, TF, TU, and YH of the downhole array. 


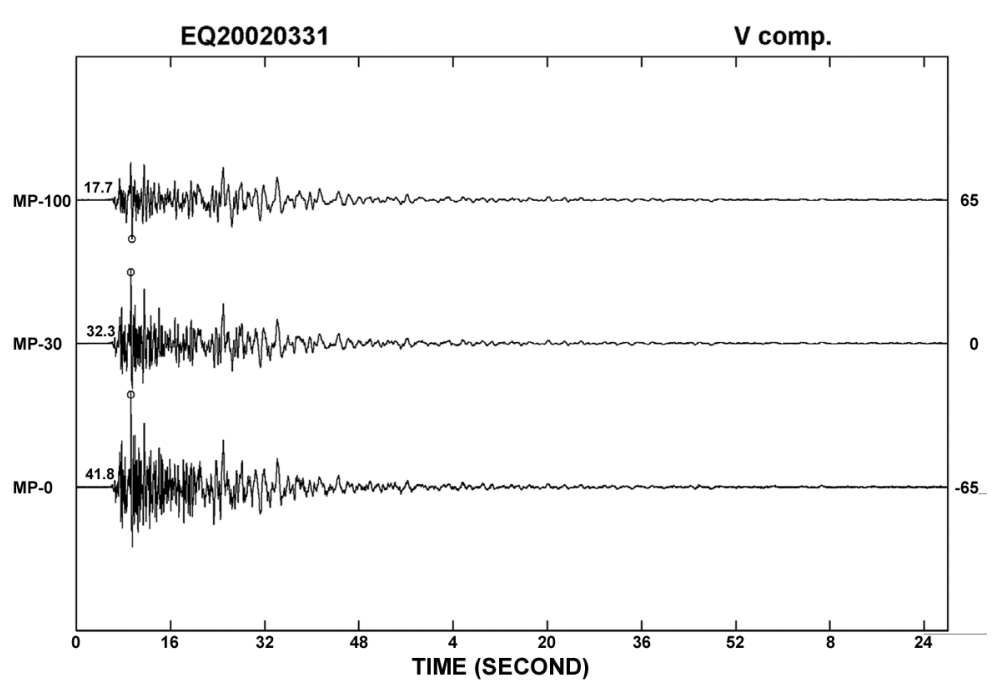

Fig. 4. An example to show the vertical-component accelerations of an earthquake of 31 March $2002\left(\mathrm{M}=6.8\right.$; epicenter: $24^{\circ} 8.39^{\prime} \mathrm{N}, 122^{\circ} 11.49^{\prime} \mathrm{E}$; depth: $\left.13.8 \mathrm{~km}\right)$ recorded at three different depths, i.e., 100,30 , and $0 \mathrm{~m}$, in a down-hole station MP. quake prediction has totally failed. Challenges regarding deterministic earthquake prediction are: (1) predictions being made in the absence of directly visible signals; (2) public pressure on seismologists for reliable predictions in seismically active areas; (3) the difficultly in debunking unfounded and non-testable predictions, especially short-term ones; (4) decisions being typically made under high uncertainty due to probability models taking many years to validate making it difficult to asses cost-benefit analysis, especially with the perceived waste of public funds and time from false predictions; and (5) public education not being adequate enough to help the layperson take the appropriate precautions given the unreliable yet sensational nature of predictions.

Regarding the four factors governing seismic risk, mentioned in the previous section, seismologists can make substantial and direct contributions to the understanding of seismic hazards. Urban seismology includes, at least, three core topics: earthquake forecasting (or earthquake rupture probability estimates), real-time earthquake warning, and the estimation of strong ground motions. These core topics are described below. the management of exposure: land-use policies; (3) the reduction of fragility: building codes, and performance-based design; and (4) the improvement of resiliency: rapid emergency response, education of the people in understanding seismic risk, and the development of insurance.

With the proper information, engineers can set building codes most suitable for building types in a particular seismic zone. These rules naturally reflect past experience with destructive earthquakes, are generally prescriptive and primarily designed to protect lives.

\subsection{Ways of Mitigating Seismic Risk}

The most direct way of preventing or reducing seismic risk is the reliable deterministic prediction of location, magnitude, and occurrence time of an earthquake. In fact, there are four kinds of prediction: time-independent hazards, time-dependent hazards, earthquake forecasting, and deterministic earthquake prediction. Considering the length of time before a future earthquake, there are long-, immediate-, and short-term predictions. If $\tau_{p}$ is the time preceding a future earthquake then the values of $\tau_{\mathrm{p}}$ are several tens to hundreds of years, several to several tens of years, and days to several months, respectively, for long-, immediate-, and short-term predictions. Time-independent hazards, time-dependent hazards, and earthquake forecasting mainly belong to long- and immediate-term predictions, while deterministic earthquake prediction can be anyone of them.

Presently, except for very few earthquakes, for example the 1972 Haicheng, China, earthquake, deterministic earth-

\subsubsection{Earthquake Forecasting}

In order to reduce earthquake induced losses, the prevailing strategy is to estimate earthquake rupture probabilities in existing active faults (cf. WGCEP 1995; Page et al. 1997). This involves assessing the probability of a large earthquake within a specified range of time (months to years), place (large region), and magnitude, including the probability gain over random occurrence and probabilities of false alarms and failures to predict.

Forecasting must also include the prediction of largersized aftershocks. In numerous cases, for example the 1999 Chi-Chi earthquake, buildings or civil structures, which were damaged, yet did not collapse during the mainshock, collapsed due to the large aftershocks. Forecasting largersized aftershocks is a significant problem in risk mitigation (Reasenberg and Jones 1989). However, although it is difficult to predict an earthquake, it does seem to be easier to forecast larger-sized aftershocks after an actual earthquake has occurred.

\subsubsection{Real-Time Early Warning Systems}

Since it is still difficult to predict earthquakes, realtime early warning systems (EWS) are effective in helping reduce the hazards from seismic activity. The CWB has developed a real-time EWS (Wu et al. 1999), which is one of the most efficient systems presently in operation around 
the world. The system provides warning time from a few to tens of seconds before the arrival of strong ground shaking caused by large earthquakes.

\subsubsection{Estimation of Strong Ground Motions}

A more direct, efficient method for earthquake loss reduction is the estimation of strong ground motions, $\mathrm{S}(\mathbf{r}, \mathrm{t})$, which can be accelerations, velocities, or displacements. $\mathrm{S}(\mathbf{r}, \mathrm{t})$ is controlled by the source, path, and site effects, denoted by $S_{0}(r, t), P(r, t)$, and $S_{i}(r, t)$, respectively, plus the instrumental response, $\mathrm{I}(\mathrm{t})$ :

$\mathrm{S}(\mathbf{r}, \mathrm{t})=\mathrm{S}_{\mathrm{o}}(\mathbf{r}, \mathrm{t}) * \mathrm{P}(\mathbf{r}, \mathrm{t}) * \mathrm{~S}_{\mathrm{i}}(\mathbf{r}, \mathrm{t}) * \mathrm{I}(\mathrm{t})$

In Eq. (2) $|\mathbf{r}|$ and t are the hypocentral (or epicentral) distance and the time instant, respectively. The source effect, $S_{0}(\mathbf{r}, t)$, includes the fault type (strike-slip, normal, or thrust), size, rise time, duration time, source scaling law, and radiation pattern. The path effect, $\mathrm{P}(\mathbf{r}, \mathrm{t})$, is dependent upon the 3-D velocity and attenuation $(\mathrm{Q})$ models. The site effect, $S_{i}(r, t)$, is influenced by geometry, layering, and nonlinear behavior of sediments. Of course, $\mathrm{S}_{\mathrm{i}}(\mathbf{r}, \mathrm{t})$ can also be influenced by other factors, e.g., fluid content etc. The three effects can be analyzed from real seismic data. On the other hand, ground motions can also be numerically simulated using the finite element, finite difference, boundary integral, and hybrid methods.

Ground motions usually decay with distance from the earthquake source. Near an earthquake fault, ground accelerations can be very large (Wen et al. 2001). In addition, rupture at velocities close to the shear-wave velocity and parallel to large fault slip causes large killer pulses, which are capable of causing substantial damage. Large magnitude earthquakes probably generate high-frequency peak ground acceleration (PGA) that is comparable to moderate earthquakes, but with longer durations. Large earthquakes also produce low-frequency ground motions that are much larger and distribute over a larger area. The understanding of longer-period ground motions is important in the design of large structures.

\section{THE TAIPEI METROPOLITAN AREA}

Although seismicity in the TMA is lower than in other areas of Taiwan, numerous earthquakes still occur (Hsu 1961, 1971; Wang 1998). Figure 5 shows the localities of $\mathrm{M} \geq 4$ shallow (in open circles) and deep (in solid circles) earthquakes occurring in the area from 1973 to 2005 . The occurrence times, locations, magnitudes, and effects of $\mathrm{M}>5$ destructive earthquakes occurring in the area are listed in Table 1 . The errors of magnitude of earthquakes occurring before 1900 are high. During the Emperor Kangshi period of the Chin Dynasty, an event may have occurred in this area in April or May of 1694, resulting in an earthquakeinduced lake and the destruction of aboriginal houses (Lin 1957; Hsu 1983b; Shieh 2000). From historical documents pertaining to damage, the magnitude of this event has been estimated by Hsu (1983b) and Tsai (1985) to be about 7. On 15 April 1909, an M7.3 earthquake took place at a depth of $80 \mathrm{~km}$ beneath the area with casualties including 9 dead and 51 injuries; there were 122 houses that collapsed, and another 1054 houses damaged (Hsu 1961).

Several distant earthquakes, i.e., the 1986 M7.8 Hualien offshore earthquake, the 1999 M7.6 Chi-Chi earthquake, and the 2002 M7.1 Hualien offshore earthquake that have also caused damage in the TMA. However, before 1970 large distant earthquakes, i.e., the 1906 M7.1 Meishan earthquake, the 1935 M7.2 Hsinchu-Taichung earthquake, the 1941 M7.1 Chungpu, Chiayi earthquake, and the 1951 M7.4 Hualien earthquake, did not cause remarkable damage in the area. The magnitudes of these earthquakes are taken from Wang and Kuo (1995). An interesting question is to what caused the differences in damage between pre-1970 and post- 1970 events. Observations show that the predominant frequencies of seismic waves, generated by distant earthquakes, are almost $0.5-1.0 \mathrm{~Hz}$ in the area (cf. Wen and Peng 1998). This would result in damage to buildings of 10 - 20 floors. Before 1970, most buildings were lower than 4 floors, and, thus, damage was minor. Since 1970, a large number of high-rise (10 - 20 floors) buildings has been constructed, thus earthquake-induced damage has also increased, even with the quality of construction having been substantially increased.

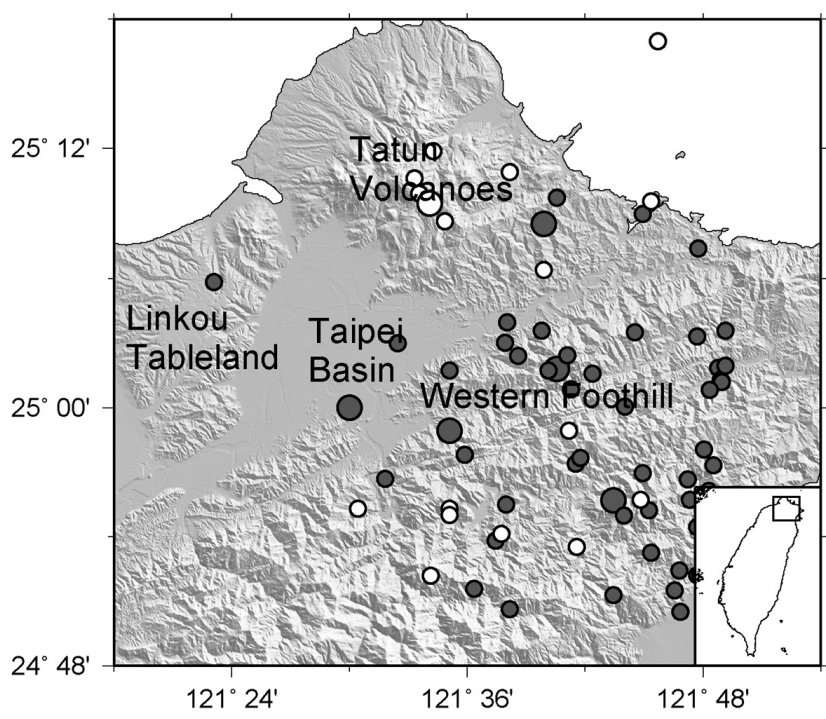

Fig. 5. Epicenters of earthquakes $(4.0 \leq M \leq 5.7)$ during $1973-2005$ : open and solid circles for shallow $(0-40 \mathrm{~km})$ and deep $(>60 \mathrm{~km})$ events, respectively (after Wang et al. 2006). 
Table 1. The $M>5$ earthquakes occurred near the Taipei Metropolitan Area.

\begin{tabular}{|c|c|c|c|}
\hline Time & Location & $\mathbf{M}$ & Effects \\
\hline $1659 / 10-11$ & Near Taipei & & Aftershocks \\
\hline $1694 / 4-5$ & Near Taipei & 7.0 & $\begin{array}{l}\text { Subsidence (Kanshi Lake) } \\
\text { Damaged houses }\end{array}$ \\
\hline $1815 / 7 / 11$ & Near Taipei & 6.5 & Minor damages \\
\hline $1853 / 5-8$ & Tatungshan & & Earthquake sound \\
\hline 1860/11-12 & Near Taipei & & Landslide \\
\hline $1865 / 11 / 6$ & Near Taipei & 6 & Landslide, death \\
\hline $1867 / 12 / 18$ & Offshore Keelung & 7.0 & Tsunami, Surface ruptures, death \\
\hline $1881 / 12 / 08$ & Near Taipei & & Minor damages \\
\hline $1909 / 04 / 15$ & $\begin{array}{l}25^{\circ} \mathrm{N}, 121.5^{\circ} \mathrm{S} \\
\mathrm{h}=80 \mathrm{~km}\end{array}$ & 7.3 & $\begin{array}{l}\text { Death: 9; Injured: } 51 \\
\text { Houses: Collapsed: } 122 \\
\text { Damaged: } 1050\end{array}$ \\
\hline 1988/07/03 & $\begin{array}{l}25.16^{\circ} \mathrm{N}, 121.57^{\circ} \mathrm{S} \\
\mathrm{h}=5 \mathrm{~km}\end{array}$ & 5.3 & Injured: 16 \\
\hline
\end{tabular}

\section{BRIEF GEOLOGY OF THE TAIPEI METROPOL- ITAN AREA}

Figure 1 shows a geological map of the TMA and its surroundings. The area is situated in the Taipei Basin and surrounded by the Tatun Volcano Group (TVG), Linkou Tableland, and Western Foothills. This basin lies on a Tertiary basement and is filled with Quaternary sediments (Wang-Lee and Lin 1987; Chang et al. 1998; CGS 1999a; Chou 2004). The contour of the thicknesses of the basin is depicted in Fig. 2. The Quaternary sediments are composed of three formations, i.e., the Sungshan formation, the Chingmei formation, and the Hsinchuang formation from top to bottom. Teng et al. $(1994,1999)$ further divided the Hsinchuang formation into the Wuku formation and Panchiou formation. The subsurface geological structures of the Taipei Basin along a line across the TMA are displayed in Fig. 6. The topmost part of the Sungshan formation is a soft layer, composed of unconsolidated sand, silt and clay with a thickness varying from $50 \mathrm{~m}$ in the southeastern part to $120 \mathrm{~m}$ in northwestern part. The lower part of the formation is dominated by silt. The Chingmei formation is full of gravels. The Hsinchuang formation is composed of sand and silt.

From the Pliocene to the Pleistocene time, three main reverse faults have developed along the western boundary of the Western Foothills in this area. From NW to SE, the three faults are the Hsinchuang fault (Wu 1965), the Kanchiao fault, and the Taipei fault, all trending in the NE-SW direction. During this time period, the Linkou area was a delta fan at the foothills of these faults, where conglomerates were widely deposited. About 0.800 m.y. ago, tectonic
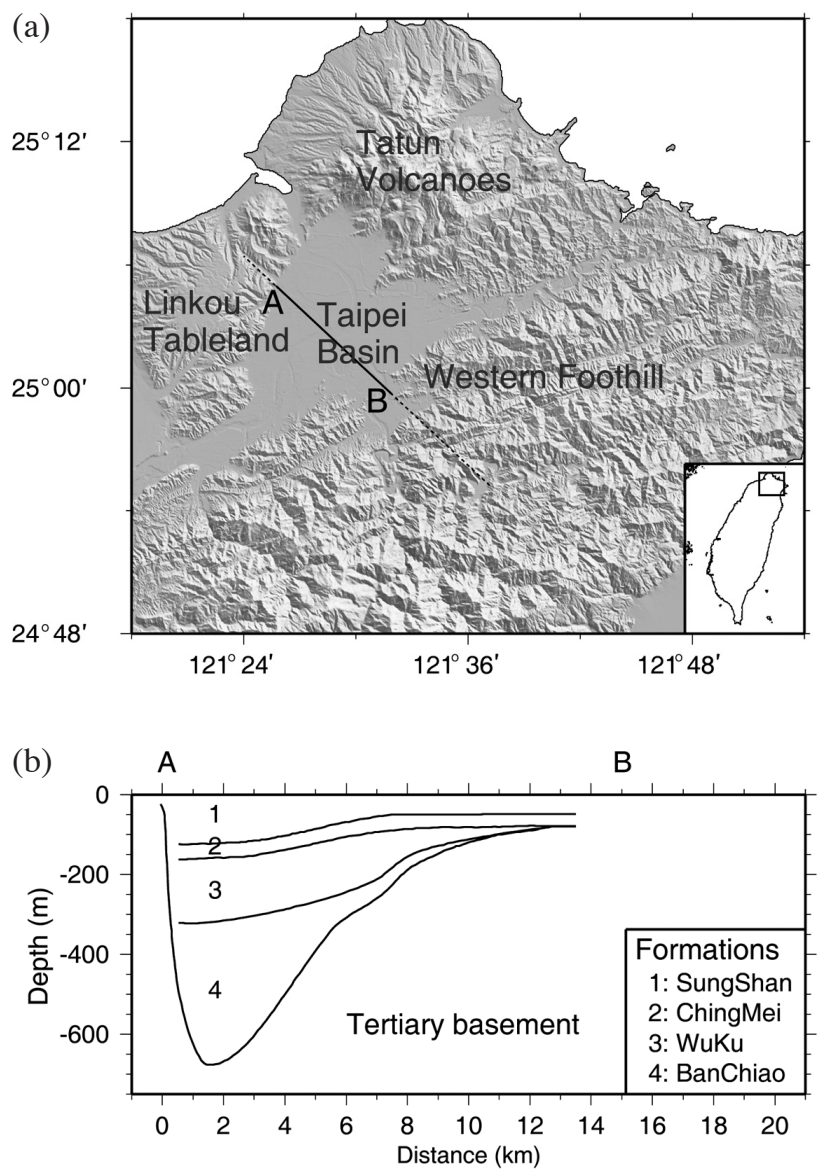

Fig. 6. (a) A map to show the Taipei Basin and surrounding geological provinces; and (b) Subsurficial geological structures in the Taipei Basin along line AB in (a) (modified from Wang 2006). 
conditions in northern Taiwan changed from compression to tension (cf. Teng 1996; Wang et al. 1999), which resulted in the formation of TVG and normal faults. A segment of the Hsinchung fault re-activated as a normal fault. This segment is called the Shangjiao fault. This tension-type tectonics led to a pull-apart mechanism, which made the Taipei Basin subside (Lee 1996; Lee et al. 1999). Thus, the deepest portion of the basin is along the NW border where the Shangiiao fault is located. This results in a half-bowl-shape basin. The cut boundary is rightly along the Shangjiao fault. (It is noted that the Shangjiao fault is called the Shanchiao or Shanjau fault by some other authors.)

The basement is shallower than $250 \mathrm{~m}$ in the south and deeper than $500 \mathrm{~m}$ in the north. This might have been caused by the formation of the Shangjiao fault. Bonilla (1977) proposed that this fault is quite young and has moved in the near past. This means that this fault could be active in the future. The old Kanchiao fault produced uplift in the basement, thus forming a geological boundary separating the basin into two parts with different basement depths and deposits (Lee 1996; Lee et al. 1999).

\section{COMPARISON OF THE TAIPEI AND LOS ANGE- LES BASINS}

Nearly half of the US's seismic risk is located in Southern California, with one-quarter concentrated in Los Angeles county alone (SCEC 2002). Hence, the Los Angeles
(LA) Basin has become the subject of much research by urban seismologists not only in the USA but also worldwide. A comparison of several items between the Taipei and LA Basins is given in Table 2. The two basins are both located in collision areas of two individual plates: the Eurasian and Philippines Sea plates for the Taipei Basin and the Pacific and Northern American plates for the LA Basin. There are some differences in geophysical quantities between the two basins: higher relative movement speed of the plates, higher seismicity, and a smaller ratio of maximum basin depth to the maximum height of mountains in the Taipei Basin than in the LA Basin. The type of faulting is mainly thrust in the former and strike-slip in the latter. There are also differences in civil structures and tradition of construction between the two basins: a larger number of overhead walkways, a bigger percentage of people living in high-rises at night, a shorter distance between two buildings, and a higher degree of mountain-slope usage for constructing houses exist in the Taipei Basin than in the LA Basin. Earth scientists in the LA Basin have developed excellent projects and obtained much experience in urban seismology. And although their knowledge and experience are invaluable to us, we ourselves still need to learn from studies of urban seismology in our area because of the above-mentioned differences. In addition, it is important to note that a destructive earthquake in the Taipei basin would lead to more difficulties in conducting rescue operations than in the LA Basin due to differences in civil structures, construction traditions, and narrower roads.

Table 2. Comparison of several items between the Taipei and the LA Basins.

\begin{tabular}{lll}
\hline Items & Taipei Basin & LA Basin \\
\hline Area & $30 \times 20 \mathrm{~km}^{2}$ & $60 \times 60 \mathrm{~km}^{2}$ \\
Population Density & High & Small to Moderate \\
Degree of Using the Mountain Slopes & High & Low \\
Number of High-rises & Large (Apartments + Offices) & Large (Mainly Offices) \\
Number of People Living in the High-rises & Large & Small \\
(Days and Nights) & & \\
Number of Overhead Walkways & Large & Small \\
Distance Between Two Buildings & Null or Small & Large \\
Density of Seismic Stations & High & Moderate \\
Moving Speed of Plates & $8 \mathrm{~cm} \mathrm{yr}-1$ & $5 \mathrm{~cm} \mathrm{yr}$ \\
Seismic Activity & High & Moderate \\
Active Faults Crossing the Basin & Yes & Yes \\
Maximum Depth of the Basin (D) & $700 \mathrm{~m}$ & $9000 \mathrm{~m}$ \\
Ratio of Maximum Depth of the Basin to & $<1$ & $>1$ \\
Maximum Height of Mountains & & \\
\hline
\end{tabular}




\section{PREVIOUS STUDIES}

\subsection{Active Faults}

Several faults have been identified by geologists in the TMA (see Fig. 1). However, those faults are only partly understood. In fact, most of them are not exactly delineated on the ground surface. The CGS classifies the identified faults in the area into secondary or third class. Using radiocarbon dating of drilled cores, Huang et al. (2003) suggested that three prehistoric earthquakes have ruptured the Shangjiao fault in the past 11000 years, and the latest event occurred around 8400 years ago.

In order to study slip rates of active faults in the TMA, Yu (2000) has deployed a GPS array and performed surveys in the area since 1992. From 1992 - 2000, small extension rates of $0.12-0.15 \mu$ strain $\mathrm{yr}^{-1}$ in the direction of azimuth $=270^{\circ}-288^{\circ}$ in the vicinity of the Chinshan and Shangjiao faults were recorded. In northern Taiwan, the average principal strain rates are: an extension rate of $0.09 \mu$ strain $\mathrm{yr}^{-1}$ along the direction of azimuth $=289^{\circ}$ and a shortening rate of $0.05 \mu$ strain $\mathrm{yr}^{-1}$ along that of azimuth $=19^{\circ}$. In addition, no significant vertical movement on the Shangjiao fault or significant slip across the Chinshan fault was detected. Before the 1999 Chi-Chi earthquake, strain rates in central Taiwan were very low (Yu et al. 1997); nevertheless, the fault broke during the 1999 Chi-Chi earthquake. Hence, a low strain rate does not mean that earthquakes will not occur.

Yang and Chen (1989) applied the transient electricmagnetic (TEM) method to locate the Chinshan fault. They assumed that this fault could still be active because of the presence of a fault within strata of the Quaternary age. From Bouguer anomaly profiles, Chen and Yeh (1991) stated that the Chinshan fault is a thrust fault with a dipping angle of $55-60^{\circ}$. Kim et al. (2005) relocated $\mathrm{M}>2$ events occurring underneath northern Taiwan during the period 1973 - 2003, and found a linear seismicity pattern dipping to the southeast. This pattern might correlate with the Chinshan fault. They also found that three $\mathrm{M} \geq 2.8$ events show normal faulting. Under the CGS's support, Chan et al. (2005a, b) conducted a project to construct a digital elevation map (DEM) using LIDAR. Results show the existence of a normal fault system in the TVG. These normal faults cut through lava flats with a few to several meters of offset, thus suggesting recent activity along the faults. From the data obtained from a micro-earthquake survey in the Taipei Basin during the period from 17 June to 20 September 2004, Chen et al. (2005) stated that seismicity on and around the Shangjiao fault is very low.

\subsection{Earthquake Catalogue}

A complete earthquake catalogue is very important for studies of seismicity and evaluations of seismic risk. Numer- ous catalogues, which include earthquakes occurring in the study area, are described below. Hsu (1961) reported some historical events from historical documents. Hsu (1983a) collected a relatively complete data set of four kinds of natural disasters caused by earthquakes, typhoons, floods, and low temperatures that occurred in Taiwan during the Chin Dynasty. Hsu (1983b) estimated magnitude values (from 5.0 to 7.5) of twenty-seven historical earthquakes occurring in the Ming and Chin Dynasties from 1644 to 1882 . Amongst them, three were in or near the TMA and one was offshore of Keelung. Tsai (1985) re-estimated the magnitude values (from 6.0 to 7.7) of eleven historical, disastrous earthquakes from 1683 to 1895 based on Hsu's data. Out of them one event occurred in the TMA.

Hsu (1961) reported disastrous earthquakes in Taiwan from 1900 to 1960 . Hsu (1971) published the first catalogue of earthquakes for the period 1936 to 1967 for $\mathrm{M} \geqq 4$ earthquakes. Also included in this catalogue are seventyfour post-1936 M $\geqq 5$ earthquakes. Later, Hsu (1980) published a revised catalogue for $\mathrm{M} \geqq 4$ earthquakes during the period 1936 to 1979 . Included are some large earthquakes that occurred from 1644 to 1896 reported in historical documents and other earthquakes detected by instruments from 1900 to 1936 . Li (1983) published a catalogue of $\mathrm{M} \geqq 5$ earthquakes. Cheng and Yeh (1989) published a catalogue consisting of document-reported earthquakes from 1604 to 1897 and instrumentally-recorded $\mathrm{M} \geqq 4$ events from 1898 to 1988 . Essentially, their catalogue is a combination of Hsu's and that published by the IES. In this catalogue, all magnitudes used in the original catalogues were transferred into a local magnitude. Wang and Kuo (1995) published a complete catalogue for $\mathrm{M} \geqq 7$ earthquakes for the period 1900 to 1996. The earthquake magnitude shown in this catalogue is equivalent to the commonly-used surfacewave magnitude, $M_{\mathrm{s}}$. Since 1953 , the CWB has published a bulletin of earthquakes (four volumes annually), reporting phases and arrival times. During the period 1972 - 1992, an earthquake catalogue including four volumes per year was published by the IES. In addition, several global earthquake catalogues also include Taiwan earthquakes. The details of which can be seen in Wang (1992). However, magnitudes are not unified in these catalogues. Wang (1992) constructed relationships among different magnitude scales. It is noted that difficulties exist in unifying magnitude scales even in a single catalogue covering a long time period when instruments installed in and the numbers of seismic stations vary.

\subsection{Seismicity}

As shown in Fig. 5, there were shallow $(0-40 \mathrm{~km})$ earthquakes in the crust and deep $(>60 \mathrm{~km})$ ones in the Wadati-Benioff subduction zone below the TMA. This is also found by other authors (e.g., Tsai et al. 1977; Wu 1978; 
Wang et al. 1983; Wang and Shin 1998; Lin 2002). Tsai et al. (1973) reported that micro-earthquakes occurr mainly in the southern zone of the TVG and that larger-sized events show normal faulting. The epicentral distributions given by Wang et al. (1983) and Kim et al. (2005) both show lower seismcity in the TMA than other areas in northern Taiwan. Wang (1988b) stated a higher b-value in northern Taiwan than in others. Kim et al. (2005) also obtained a high b-value in the TGV. Wang et al. (1994) stated that except for the earthquakes in the subduction zone, the events occurring in northern Taiwan are usually shallow. Kim et al. (2005) also obtained similar results for $\mathrm{M}>2$ events that occurred during 1973 to 2003. They also found that three $M \geq 2.8$ events occurring below the TVG show normal faulting. From a seismic survey, Chen and Yeh (1991) stated that most of the micro-earthquakes $(0.2 \leq \mathrm{M}<3.0)$ in the TVG were located at depths shallower than $10 \mathrm{~km}$ and show normal faulting. Lin et al. (2005) stressed that earthquakes occurring underneath the TVG are located mainly at a depth range of 2 $4 \mathrm{~km}$. From the depth profile of microearthquakes with $\mathrm{M}<2.8$, Konstantinou et al. (2007) mentioned that all events have a focal depth less than $6 \mathrm{~km}$. Hence, in the area, high bvalues, shallow focal depths, and normal faulting might all show high geo-temperature caused by past volcanic activity. Based on the concept proposed by Scholz (1990), these studies imply that the seismogenic zone below the TVG is thinner than other zones. From the micro-earthquake data recorded by a seismic array deployed from 17 June 2004 to 20 September 2004, Chen et al. (2005) reported that seismic activity was very low below the Taipei Basin and the events were located mainly beneath the TVG. Wang et al. (2006) investigates epicentral distribution, depth distribution, and temporal sequences of $\mathrm{M} \geq 4$ earthquakes occurring from 1973 - 2005. Shallow earthquakes mainly located in a depth range from $0-10 \mathrm{~km}$ north of $25.1^{\circ} \mathrm{N}$, and down to $35 \mathrm{~km}$ in depth for earthquakes south of $25.1^{\circ} \mathrm{N}$. After 1988 , no $\mathrm{M} \geq 4$ shallow event was located within this area. Deep events occurred more or less uniformly during the study time period. The annual number of shallow earthquakes decreases with time from 1973 to 1988 , and varies year to year for deep events. They also applied the frictional rupture and quasi plastic (FR/QP) transition model (Sibson 1977) to interpret the depth distribution of shallow earthquakes.

Chen and Yeh (1991) and Chen et al. (1995) reported that there is no remarkable correlation between micro-earthquake activity and the Chinshan fault. Chen et al. (2005) stressed that there is no remarkable correlation between micro-earthquake activity and the Shangjiao fault. Lin (2005) stressed that seismcity underneath the Taipei Basin, which was usually low, began to slightly increase during the construction phase and rose sharply upon the completion of the Taipei 101. Two felt earthquakes astonishingly occurred beneath the completed building. Of course, there is some debate about this building-induced seismicity.

\subsection{Source Properties}

The scaling law of source spectra is necessary for evaluations of strong ground motions. The body-wave earthquake source spectrum is controlled by seismic moment $\mathrm{M}_{\mathrm{o}}$ and corner frequency, $\mathrm{f}_{\mathrm{c}}$. Theory and observation show that when the frequency, $f$, is larger than $f_{c}$, the spectral amplitude decays in a power-law function of $\omega^{-a}$, where " $a$ " is the exponent of the function. Commonly accepted power-law functions have either a $\omega^{-2}(\omega=2 \pi \mathrm{f})$ or $\omega^{-3}$ form, which are generally referred to as the $\omega^{-2}$ and $\omega^{-3}$ models, respectively, (cf. Aki 1967; Brune 1970). The scaling laws of source parameters of Taiwan's earthquakes were studied by some authors (Wang 1985, 1992, 1998; Cheng and Yeh 1989; Li and Chiu 1989). The details of which can be found in Wang (1992). In addition, the scaling laws of source spectra of earthquakes in Taiwan were studied by numerous authors (e.g., Hwang and Kanamori 1989; Tsai et al. 1994; Tsai 1997; Huang and Yeh 1999; Sokolov et al. 2000a, 2002a, b, 2003; Huang et al. 2001b; Hwang et al. 2001a, b; Huang and Wang 2002; Huang et al. 2002; ).

Among the faults in the TMA (see Fig. 1), the Chinshan and Shangiiao faults are particularly important, because they have been long assumed to be related to a $M=7$ earthquake, which resulted in a lake, the so-called the Kanshi Lake which came into existance in 1694 during the Emperor Kanshi rein of the Chin Dynasty (Lin 1957; Hsu 1983b). In order to form an earthquake-induced lake, the average vertical displacement on the fault plane should be several meters. Of course, there is some debate about the possibility of the occurrence of this event. Lee (1993) and Shyu et al. (2005) assumed the possibility of forming a lake by the 1694 event. On the other hand, Lee et al. (1999) and Lin (2001) disagreed on the connection between the formation of the Kangshi Taipei Lake and the failure of the Shangjiao fault. In order to explore the problem, two questions must be answered. Firstly, how big is the largest earthquake that can independently occur on either the Chinshan or Shangjiao fault? Secondly, can the Chinshan and Shangjiao faults fail simultaneously?

The answer to the second question will be explained in the next sub-section. In order to answer the first question, Shyu et al. (2005) estimated the magnitudes of potential earthquakes rupturing 20 recognized active faults in and surrounding Taiwan by using relationships inferred by Wells and Coppersmith (1994). Their estimated value for an earthquake possibly simultaneously rupturing the Chinshan-Shangjiao fault system, with a total length of $45 \mathrm{~km}$ and a fault width of $15 \mathrm{~km}$, is 6.9 . However, they might have over-estimated fault width, because the geo-temperature below the two faults, especially for the Chinshan fault, is high. Wang (2008) evaluated the earthquake magnitude (M), maximum displacement $\left(\mathrm{D}_{\max }\right)$, and average displacement $\left(D_{\text {ave }}\right)$ of an earthquake, which would rupture either fault, 
from the relationships inferred by Well and Coppersmith (1994). The optimum values of the three parameters are: (1) $\mathrm{M}=6.6, \mathrm{D}_{\max }=0.97 \mathrm{~m}$, and $\mathrm{D}_{\mathrm{ave}}=0.42 \mathrm{~m}$ for the Shangjiao fault; and (2) $\mathrm{M}=6.7, \mathrm{D}_{\max }=1.35 \mathrm{~m}$, and $\mathrm{D}_{\mathrm{ave}}=0.55 \mathrm{~m}$ for the Chinshan fault; and (3) $\mathrm{M}=7.0, \mathrm{D}_{\max }=3.28 \mathrm{~m}$, and $\mathrm{D}_{\mathrm{ave}}=1.15 \mathrm{~m}$ for the Chinshan-Shangjiao fault system. The southern end of the Chinshan fault touches the Taipei Basin. At the two ends of a fault, the displacements are usually small (cf. Scholz 1990); consequently, the Kangshi Taipei Lake might not have been induced by a rupture of the Chinshan fault. On the other hand, the upper bound of $\mathrm{D}_{\max }$ for the Shangjiao fault is only $0.97 \mathrm{~m}$. This does not seem capable of causing an observable lake because the depth, with a maximum value of $0.97 \mathrm{~m}$ on the fault, of subsidence of the ground surface decreases with distance from the surface trace of the fault. If the Chinshan-Shangjiao fault system, with a normal Chinshan fault, breaks, it would be possible to produce a small-scaled, shallow pond, because of $\mathrm{D}_{\text {ave }}=$ $1.15 \mathrm{~m}$ and $\mathrm{D}_{\max }=3.28 \mathrm{~m}$. However, since the Chinshan fault was not active in past $2.8 \mathrm{Ma}$ as mentioned above, the possibility of forming the Kangshi Taipei Lake by the 1694 event is very low.

\subsection{Fault Interaction}

It is not easy to answer the second question, because the Chinshan and Shangjiao faults show thrust and normal faulting, respectively. Different mechanisms work for the two faults. Meanwhile, the Chinshan fault is in the TVG. The geo-temperature below it would be higher than that beneath the Shangjiao fault (cf. Wang 1988b; Lin et al. 2005), and, thus, the thicknesses of seismogenic zones below the two faults are different. In order to answer the question, Wang et al. (2008) evaluated the stress re-distribution on a fault caused by a failure in the other by computing static Coulomb failure stress changes on the former due to a failure in the latter. Since detailed information of the two faults is incomplete, numerical simulations were made for numerous combinations of the Shangjiao and Chinshan faults, with different dip angles and average displacements. The results show that for the two faults, no matter which one breaks, the other fault can be triggered and the ruptures propagate northward and southward, respectively, for the Chinshan and Shangjiao faults. A failure in the less steep normal-type Shangjiao fault is capable of triggering the steeper thrusttype Chinshan fault, and a failure in the steeper thrust-type Chinshan fault is capable of triggering the less steep normal-type Shangjiao fault.

\subsection{Velocity, Attenuation, and Density Models}

In order to map the subsurface of unconsolidated sediments in the Taipei Basin, it is necessary to perform seismic reflection experiments across faults and to analyze core samples and well-loggings from boreholes. From seismic and borehole data, Hsieh et al. (1994) and Wang et al. (1994) first mapped the bottom of Sungshan, Chingmei, and Hsinchuang formations and the basement. However, except for the Sungshan formation, contours are not complete. From the seismic reflection experiments in the Kwangtu plain, Shih (2001) stated the strata uniformly dip from northeast to southwest. Several authors (Wang et al. 1995, 1996; Hsieh et al. 1999; Wang and Sun 1999) inferred the velocity model of the Taipei Basin. Wang et al. (2004b) revised their 1995 model and concluded that the three layers of the Sungshan formation are specified with low $\mathrm{S}$-wave velocities, $\mathrm{V}_{\mathrm{s}}$, i.e., 170, 230, and $340 \mathrm{~m} \mathrm{~s}^{-1}$, respectively. The velocities in the Chingmei, Wuku, and Banchiao formations are, respectively, 450, 600, and, $880 \mathrm{~m} \mathrm{~s}^{-1}$. The uncertainties are higher for the latter two values than the first one. The velocity of the Tertiary basement is about $1500 \mathrm{~m} \mathrm{~s}^{-1}$. The velocity model is shown in Table 3 . The velocity model has been digitized with a grid of $200 \times 200 \times 200 \mathrm{~m}^{3}$.

The 3-D velocity tomography in the TMA can be ob-

Table 3. Velocity model of the Taipei Basin (after Wang et al. 2004b).

\begin{tabular}{|c|c|c|c|c|}
\hline \multirow{2}{*}{ Formation } & \multicolumn{2}{|c|}{ Depth (meters) } & \multirow{2}{*}{$\begin{array}{c}\mathbf{v}_{\mathrm{p}} \\
\left(\mathrm{m} \mathrm{sec}^{-1}\right)\end{array}$} & \multirow{2}{*}{$\begin{array}{c}\mathbf{v}_{\mathrm{s}} \\
\left(\mathrm{m} \mathrm{sec}^{-1}\right)\end{array}$} \\
\hline & Northwest & Southwest & & \\
\hline \multirow{3}{*}{ Sungshan } & $0-20$ & $0-15$ & 450 & 170 \\
\hline & $20-50$ & $15-35$ & 1500 & 230 \\
\hline & $50-100$ & $35-100$ & 1600 & 340 \\
\hline Chingmei & $100-160$ & $50-100$ & 1800 & 450 \\
\hline Wuku & $160-320$ & $100-200$ & 2000 & 600 \\
\hline Panchiou & $320-700$ & $200-300$ & 2200 & 880 \\
\hline Basement & & & 3000 & 1500 \\
\hline
\end{tabular}


tained from the results inferred by Rau and Wu (1995), Ma et al. (1996), and Kim et al. (2004) for the whole Taiwan region. Their images all show a low-velocity zone in the shallow layer of the TVG. Ma et al. (1996) interpreted this lowvelocity zone using chemical in-heterogeneity. Rau and Wu (1995) and Kim et al. (2004) also obtained well-distributed 3 -D velocity structures of the subduction zone underneath northern Taiwan. The Moho depth is about $40 \mathrm{~km}$ inferred by Rau and Wu (1995), 30 - $35 \mathrm{~km}$ by Ma et al. (1996), and 36 - $40 \mathrm{~km}$ by Kim et al. (2004).

From the PGA, Chang and Yeh (1983) obtained the Q-f relations for $\mathrm{f}=1-10 \mathrm{~Hz}$ in northeastern Taiwan, which includes the eastern part of the TMA. Results are: $\mathrm{Q}=90 \mathrm{f}$ as $\mathrm{h}<11 \mathrm{~km}$ and $\mathrm{Q}=228 \mathrm{f}^{1.1}$ as $\mathrm{h}<80 \mathrm{~km}$. In the frequency range 2 - $6 \mathrm{~Hz}$, Wang (1988a) obtained Q $=70$ and 126, respectively, for the $\mathrm{P}$ - and $\mathrm{S}$-waves in northern Taiwan. From coda waves, Wang and Liu (1990) obtained $\mathrm{Q}=125 \mathrm{f}^{0.79}$ for $\mathrm{f}=1-10 \mathrm{~Hz}$ in northern Taiwan. A complete description about the Q values in Taiwan before 1990 can be found in Wang (1993). Chen et al. (1996) inferred a 3-D Q model of Taiwan. Results show a high-Q zone, dipping to the southeast, underneath northern Taiwan. There are uncertainties in their Q model, because they inferred the model based on an old velocity model. From strong-motion data, Sokolov et al. (2000a, b) inferred $\mathrm{Q}=225 \mathrm{f}^{1.1}$ for the Taiwan region.

There is a lack of a detailed density model right below the Taipei Basin. From gravity surveys, Tzou and Yu (1987) inversed the density model in the TVG north of the Taipei Basin. The model shows three layers with different densi-

(a)

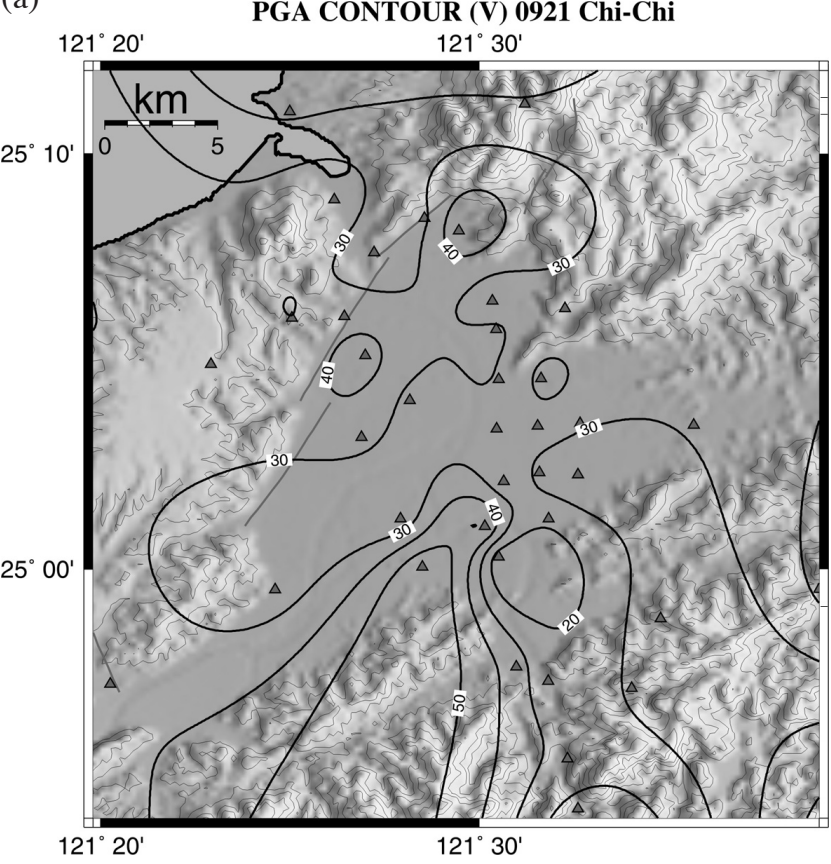

ties: $2.40 \mathrm{gm} \mathrm{cm}^{-3}$ in the range 0 to $400 \mathrm{~m}, 2.45 \mathrm{gm} \mathrm{cm}^{-3}$ in the range 400 to $1600 \mathrm{~m}$, and $2.55 \mathrm{gm} \mathrm{cm}^{-3}$ below $1600 \mathrm{~m}$. In the basin the thickness of sediments ranges from 100 to $700 \mathrm{~m}$; while outside the basin, the sediments become thin. The 3-D velocity tomography (e.g., Ma et al. 1996) shows that the deeper structures below both the TVG and the basin are similar. Hence, Huang et al. (2007b) took the density $\left(=2.45 \mathrm{gm} \mathrm{cm}^{-3}\right)$ of the second layer beneath the TVG to be that of the basement of the Taipei Basin.

\subsection{Strong Ground Motions}

In order to investigate strong ground motions, first it is necessary to analyze the characteristics of ground motions and site effects. Several authors (Wen et al. 1995a, b, 1999; Wen and Peng 1998; Sokolov et al. 2000b, 2001; Sokolov and Jean 2002; Chen 2003; Fletcher and Wen 2005) did such studies in the TMA. Wen and Peng (1998) and Wen (2005) showed that the spatial distribution of site amplifications depends on the incidence direction of waves into the Taipei Basin. They also stressed that two areas (one in east Taipei and the other in northwest Taipei) with high site amplifications at a low-frequency regime $(0.2-1 \mathrm{~Hz})$ are associated with the shape of the Tertiary basement and the top soft soils in the Sungshan formation. For a higher frequency band $(1-3 \mathrm{~Hz})$, the amplifications occur at places near the north, east, and south basin edges. Figure 7 is an example to show the spatial distributions of vertical-component PGA generated from the 1999 Chi-Chi and 2002 offshore Hual-

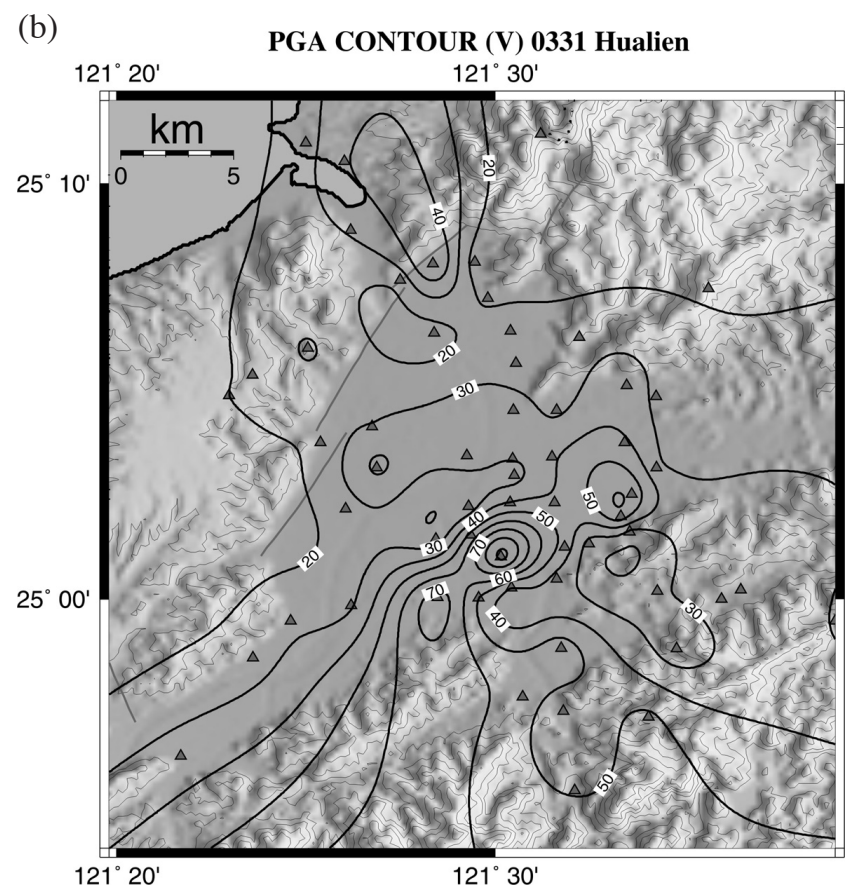

Fig. 7. The contours of vertical-component PGA for two earthquakes in the Taipei metropolitan area for two large earthquakes: (a) for the 1999 Chi-Chi earthquake and (b) for the 2002 offshore Haulien earthquake. 
ien earthquakes. The above-mentioned differences can be seen in this figure. From a comparison of the S-wave velocity structure with the distribution of average PGA over 50 earthquakes, Wang and Lee (2002) stated that larger PGA is associated with lower S-wave velocity. For the $\mathrm{M}_{\mathrm{w}} 7$ Hualien offshore earthquake of 31 March 2002, which is about $110 \mathrm{~km}$ away from Taipei, Chen (2003) reported that the recorded PGA values in the Taipei Basin vary by a factor of 5. He also suggested that the high PGA in the southeastern part of the basin can be interpreted as the PmP, SmP, and SmS phases, which are reflected from the Moho and amplified by soft sediments.

In order to study site effect, the site condition of a strong-motion station must be classified. The US's criteria to classify sites (cf. Lee et al. 2001) are based on $\mathrm{V}_{\mathrm{s}}$ : the ClassA site with $\mathrm{V}_{\mathrm{s}}>1500 \mathrm{~m} \mathrm{~s}^{-1}$, the Class- $\mathrm{B}$ one with $\mathrm{V}_{\mathrm{s}}=760$ - $1500 \mathrm{~m} \mathrm{~s}^{-1}$, the Class-C one with $\mathrm{V}_{\mathrm{s}}=360-760 \mathrm{~m} \mathrm{~s}^{-1}$, the Class-D one with $\mathrm{V}_{\mathrm{s}}=180-360 \mathrm{~m} \mathrm{~s}^{-1}$, and the Class-E one with $\mathrm{V}_{\mathrm{s}}<180 \mathrm{~m} \mathrm{~s}^{-1}$. Based on this criteria, Lee et al. (2001) classified the 708 free-field strong-motion station sites in Taiwan by comparing surficial geology with the values of $\mathrm{v}_{\mathrm{s}}$. This can be seen in Table 1 of Lee et al. (2001). From the well-logging data, Huang et al. (2005, 2007a) claimed that the classification made by Lee et al. (2001) must be corrected. In the Taipei Basin, 13 station sites must be re-classified. Huang et al. (2007b) showed that among the 18 sites in the Taipei metropolitan area, the numbers of sites of different classes are 1 for the Class-B site, 6 for the Class- $\mathrm{C}$ sites, 10 for the Class-D sites, and 1 for the Class-E site. The Class$\mathrm{B}$ and $\mathrm{C}$ stations sites are located at the mountains outside the Taipei Basin, while the Class-D and E ones are inside the basin. From well-logging data, Huang et al. (2007b) also evaluated the frequency-dependent site amplifications at higher frequencies in the TMA. Results show that $\mathrm{V}_{30}$, which is the average $\mathrm{S}$-wave velocity in the topmost $30 \mathrm{~m}$, is a significant factor in classifying the station sites, and the amplifications at all sites in the study are larger than 1 and a function of frequency. Four approaches are usually used to evaluate the site effects from seismic data. The first way (cf. Zhang 2004) is a comparison between the Fourier amplitude spectrum at a site and that at a reference hard-rock site, with nearly flat response. But, it is difficult to locate a perfect reference site. The second way (cf. Lermo and Chávez-García 1993 ) is the calculation of horizontal-to-vertical spectral ratio at a site. The third way (cf. Sokolov et al. 2004) is the ratio of the Fourier amplitude spectrum of ground motions to that simulated from a so-called "very-hard-rock model" or "absolute-source-spectra model," which is assumed to have no site effects. For this way, the precise source and path effects are needed. The fourth way is a comparison between observed ground motions and calculated values based on a measured velocity model.

Lee et al. (2001) studied the response spectra for $\mathrm{f} \geq 0.3 \mathrm{~Hz}$ and the horizontal-to-vertical spectral ratios for
$0.3 \leq \mathrm{f} \leq 33.3 \mathrm{~Hz}$. Sokolov et al. (2004) established the empirical amplification functions in the frequency range 0.1 $10 \mathrm{~Hz}$ as the ratio between Fourier amplitude spectra of recorded accelerograms and those simulated based on a hypothetical hard rock model. Zhang (2004) evaluated the site amplification, with attenuation, for $0.7 \leq \mathrm{f} \leq 6 \mathrm{~Hz}$. The latter two studies are both based on the site classification by Lee et al. (2001). As mentioned below the classification is not correct for numerous stations. Clearly, Sokolov et al. (2004) provided the model-based site effect, and others gave the reference-site-based one.

Sokolov et al. (2001) constructed the empirical models for site- and region-dependent ground-motion parameters in the TMA. It is noted that there could be some errors in their results, because their evaluations were based on the site classification by Lee et al. (2001). Using the quarterwavelength approximation method proposed by Boore and Joyner (1997), Huang et al. (2007b) evaluated the site amplitudes with $\mathrm{f}>1 \mathrm{~Hz}$ from well-logging velocity and density data measured in shallow holes near 18 strong-motion station sites in the TMA. Results show that at a unique Class-B site, site amplification first decreases and then increases with increasing frequency. At a unique Class-E site, site amplification first increases and then decreases with increasing frequency, with a peak almost at $\mathrm{f}=5 \mathrm{~Hz}$. At the Class-C and D sites, except for the data point with $\mathrm{f}=$ $0.01 \mathrm{~Hz}$, site amplification first increases with frequency, and then become flat when $\mathrm{f}>10 \mathrm{~Hz}$.

Wen et al. (1995a) also simulated 3-second ground motions by using the boundary integral method. However, the basin effect is less significant for a 3 -second wavelength. Of course, simulations for shorter-period signals are necessary for seismic risk mitigation. Lee et al. (2008) simulated 3D ground motions with frequencies up to $3 \mathrm{~Hz}$ in the Taipei Basin using the spectral-element method. Thick recent deposits make the basin unable to suffer strong ground motions, thus leading to serious damage, even though earthquakes occur far away from the area.

\subsection{Water Dam}

The Feitsui Dam is the major source supplying water to the TMA. The safety of this dam is very important for the area, because a collapse of the dam would lead to widespread flooding and loss of large amounts of water. For example, the collapse of the Shihkang Dam during the 1999 Chi-Chi earthquake caused a serious problem with water supply to the Taichung area for a long time. High seismicity in Taiwan and thick deposits of mud inside this dam could weaken it. In order to investigate strong ground motions at this dam due to earthquakes, an array, currently consisting of six accelerometers, has been installed since 1977 (Huang and Chiu 1999). Chiu and Huang (1992) and Huang and Chiu $(1995,1999)$ analyzed and numerically modeled free- 
field accelerograms along the Feitsui Canyon. Their results show that effects on ground motions caused by the dam itself can be ignored; the amplitudes of ground motions on the slopes of the canyon are larger than those at the trough, and except for the high-frequency regime, modeled waveforms can fit observed seismograms well.

\section{FUTURE PROBLEMS OF URBAN SEISMOLOGY IN TMA}

\subsection{Main Problems}

In order to mitigate seismic risk in the TMA, three research topics must be conducted soon. They are: (1) earthquake probability forecasting (including forecast of largersized aftershocks); (2) construction of local or on-site early warning system; and (3) estimation of strong ground motion. Multi- and inter-disciplinary studies are needed for these three areas. In this article, only the seismological aspect is included. Although urban seismology is an applied science, some basic studies are still necessary. Main items of research are here described. Of course, these items can also be applied in other urban areas.

\subsubsection{Earthquake Probability Forecasting}

Statistic estimates of earthquake rupture probability rely on comprehensive knowledge of regional tectonics, long- and short-term slip rates of active faults, paleo- seismicity, historical earthquakes, current seismicity, fault geometry, and stress re-distribution after a large earthquake. Probabilistic hazard analysis may be underestimated due to a lack of large earthquakes, because they do not frequently occur. Hence, inference from paleo- and historical events is important for this subject. The research items are described below.

\section{Active Faults}

As mentioned above, the CGS classifies the identified faults in the TMA into second or third classes. It is noted that although the Chelungpu fault was classified as second class before the 1999 Chi-Chi earthquake, it did rupture and cause extensive damage. Therefore, re-examination or re-classification of identified faults in the area is strongly necessary. In addition, un-exposed faults of lethal potential must be found. The long-term slip rate, recurrence characteristics, displacement per event, and depth of locking and current loading must be comprehensively investigated. Hence, more surficial (geological, seismic, and geophysical) surveys, trenching, and drilling of boreholes are needed. Of course, new aerial and space techniques, such as GPS, InSAR, LIDAR etc. are also invaluable to understanding these issues.

\section{Paleoseismicity}

In order to evaluate earthquake probability in the area, paleoseismicity must be explored through trenching across several potential active faults. Paleo-events can be identified from existing slip on possible fault planes. After the Chi-Chi earthquake, Taiwan's geologists garnered invaluable experience from trenching, for example see the work of Chen et al. (2004). Essentially, two different models, i.e., time- and slip-predictable models, have been proposed to describe recurrence of earthquakes (cf. Wang 2005). Trenching data can help seismologists to examine which model is more acceptable. Although Huang et al. (2003) did study the paleoseismicity of the Shangjiao fault, this kind of research requires even more in-depth study of the active faults of the TMA.

\section{Geometry and Characteristics of Faults}

The characteristics of a fault zone, including geometry, displacements, and physical properties, are some of the principal elements of earthquake probability evaluation and strong-motion estimation, and must be comprehensively studied. Dense seismic reflection experiments can map fault surfaces very precisely (cf. Wang et al. 2004a, 2005). A significant way to study the characteristics of a fault zone is to analyze core samples obtained from boreholes. However, current techniques for seismic reflection and the drilling of boreholes can only provide information regarding shallow fault structures. In order to map deep fault structures, the wide-angle shallow seismic reflection method proposed by Wang et al. (2004a, 2005) and the study of the spatial distribution of re-located micro-earthquakes have to be done in the near future. Of course, there are some difficulties regarding conducting the first method in the TMA, because of its high population density.

\section{Fault Interaction}

There is a basic question: Can one earthquake trigger others? This includes short- and long-range triggering. For short-range triggering, the change and re-distribution of static stresses surrounding a broken fault after an earthquake are evaluated (cf. Wang et al. 2008). The areas with an increase in static stresses are potential candidates of further earthquakes. This mechanism is also important for studying the occurrences of aftershocks. For long-range triggering, faults in an area could be triggered by a distant earthquake due to the incidence of seismic waves (Simpson 1986). This is mainly due to dynamic triggering. Currently, in the TMA only the interaction between two faults has been studied (Wang et al. 2008). More studies concerning the interaction amongst faults in the TMA must be conducted. 


\section{Historical Earthquakes}

The first seismic instrument was installed at Taipei in 1897. Hence, the occurrence times and hypocenters of earthquakes occurred before that year cannot be determined from seismic data and thus, only the events with historical documents of earthquake-induced damage can be considered. Meanwhile, only a few moderate events have been located in the TMA since the installation of the first seismic station (Wang 1998). The possible locations, magnitudes, and damage of historical earthquakes should be investigated from historical documents using current knowledge and techniques.

\section{Correlation between Larger-Sized Aftershocks and the Mainshock}

As mentioned above, it is difficult to predict an earthquake, but it seems easier to forecast larger-sized aftershocks after an earthquake. For this purpose, the correlation between a mainshock and its aftershocks, especially for the largest aftershock (cf. Wang and Wang 1993), must be constructed for earthquakes occurring in the TMA.

\subsubsection{Construction of Regional and On-Site Early Warning Systems}

This means a hybrid use of regional and on-site earthquake early warning systems in the rapid transportation system, nuclear plants, large civil structures and etc. The CWB has developed a real-time EWS (Wu et al. 1999), which can provide a warning time from a few to tens of seconds before the arrival of strong ground motion caused a large earthquake. For example, about 102 seconds after the 1999 $M_{s}$ 7.6 Chi-Chi, Taiwan, earthquake, good estimates of the hypocenter and magnitude, and a shaking map were provided by the system to the government and the public $(\mathrm{Wu}$ et al. 2000). The earthquake reporting time can be significantly shortened using a smaller network (Wu et al. 1997). Under the EWS, the CWB has been developing a virtual sub-network (VSN) (Wu and Teng 2002), which is eventdependent and whose configuration varies with time. The VSN can substantially reduce warning times.

\subsubsection{Estimation of Strong Ground Motions}

As mentioned above, strong ground motions are controlled by source, path, and site effects. The three effects are described below.

\section{Source Effect: Source Properties}

Although numerous studies concerning the scaling laws of source spectra and parameters for earthquakes in Taiwan have been made, no commonly accepted scaling law has been constructed for simulations of strong ground motions. Hence, more studies about this subject, especially for the events in and near the TMA, should be done in the near future. In areas where the source properties of past earthquakes were studied, results can be directly used to represent the source effect. However, in the TMA, where the source properties are unknown, an acceptable source model must be constructed for ground-motion simulations.

\section{Path Effect: Velocity, Q, and Density Models}

In addition to source characteristics, the principal elements required for numerical simulations of strong ground motions include: (a) detailed subsurface mapping of unconsolidated sediments in the Taipei Basin; (b) mapping of the Moho depth; (c) seismic-wave attenuation (Q) modeling; and (d) construction of adequate numerical mesh models. Since only limited values of $\mathrm{V}_{\mathrm{s}}$ were directly measured from well loggings, $\mathrm{V}_{\mathrm{s}}$ must be calculated from $\mathrm{V}_{\mathrm{p}}$ based on a theoretical relation between the two parameters. However, such a relation cannot be completely applied to sediments. Since $\mathrm{V}_{\mathrm{s}}$ is important for strong motion evaluations, more measures of $\mathrm{V}_{\mathrm{s}}$ must be made. As mentioned above, there is a lack of a density model below the TMA. It is necessary to perform a detailed gravity survey in the TMA, because of the density control site amplifications. In addition, as mentioned above the velocity model was digitized with a grid of $200 \times 200 \times 200 \mathrm{~m}^{3}$. The length of the grid is $200 \mathrm{~m}$, for which the characteristic frequencies are $0.85,1.15$, and $1.70 \mathrm{~Hz}$, respectively, associated with three $\mathrm{S}$-wave velocities of the Sungshan formation, i.e., 170, 230, and $340 \mathrm{~m} \mathrm{~s}^{-1}$ (see Table 3). This is due to the limitation of resolution for shallow seismic reflection experiments done previously. However, higher frequencies are necessary for seismic hazard assessment. In order to simulate higher- frequency strong ground motions, a digital model, at least, with a grid of $100 \times 100 \times 100 \mathrm{~m}^{3}$ is definitely required. This requests execution of higher resolution seismic reflection experiments in the TMA.

\section{Site Effect: Characteristics and Evaluation of Site Effect and Strong Motions}

The characteristics of strong ground motions, including inhomogeneous spatial distribution of strong ground motions and the correlation between strong motions and sediments, in the area have been investigated for a long time, and numerous significant results obtained. Nevertheless, a 4-D picture, including 3-D spatial distribution and temporal variation, of strong motions must be constructed. This will rely on long-term observations of strong motions using both surface and down-hole seismic arrays. As shown in Table 2, a high- degree use of mountain slopes makes evaluations of strong motions in such areas important. But, a small ratio 
for the maximum depth of the basin to the maximum height of the mountains makes the problem difficult, because topographic effect cannot be ignored in numerical simulations.

Although Huang et al. (2007b) evaluated frequencydependent site amplifications for $\mathrm{f}>1 \mathrm{~Hz}$ in the TMA, their study is not enough for engineering purposes for which site amplifications must be evaluated to the low frequency regime, at least down to $0.1 \mathrm{~Hz}$, for seismic hazard assessment.

Nonlinear behavior of soils can affect site amplifications (cf. Boore et al. 1989). Under strong ground shaking, soils behave like liquid (cf. Astaneh 1989). This liquefaction effect shows nonlinear behavior for soils. Serious liquefaction makes buildings incline or collapse. The degree of liquefaction depends upon soil characteristics and the depth of the water table. The topmost layer of the Taipei Basin is full of soft soils and the water table in numerous places near the Tanshui and Keelung rivers is shallow. Luckily, there was no remarkable liquefaction in the area during several distant large events. One of the reasons for this was the absence of building construction in areas most likely to experience liquefication. The other reason is a decrease in seismic-wave amplitudes due to in-elastic attenuation and geometrical spreading. These two reasons possibly reduced the possibility of yielding liquefaction. Nevertheless, liquefaction would be inevitable in the Taipei Basin during strong ground shaking from large earthquakes occurring directly below the area. Such events will lead to stronger horizontal shaking than distant ones because of less attenuation of the seismic waves.

The construction of buildings or civil structures could change the geological condition surrounding them. Interaction between buildings and sediments could influence strong motions near buildings, and is a significant issue in engineering seismology. However, this interaction is poorly understood due to limited data. Naturally, the effect caused by small buildings or civil structures is negligable; however, for a high-rise, like the Taipei 101, such interactions might be significant. Obviously, Taipei 101 makes for an excellent candidate for the study of building-sediment interaction. For this reason, a dense seismic array inside and outside Taipei 101 must be installed soon.

\subsection{Related Problems}

In addition to the main problems, the following problems relating to earthquakes are also important for the TMA.

\section{Landslide}

During an earthquake, strong ground shaking often produces landslides (e.g., Huang et al. 2001a). For example, the 1999 Chi-Chi earthquake caused small-scaled landslides in the TMA. Since Taiwan is in the sub-tropics, there are heavy and continuous monsoonal rains as well as typhoons in the summer and fall months. Landsides often occur after heavy rain. Strong ground shaking makes soils in the mountain slopes loose, thus more conducive to landslides.

Although there have been landslides caused by strong ground shaking in the TMA, only few useful data for indepth research is available. Recently, IES's Dr. Lee (personal communication) found a positive correlation between sediments, which might result from landslides in the Wu-TsuShan, beneath East Lake in the TMA and historical events. This is a significant problem worthy of further study.

\section{Water Dams}

Although there exist several studies regarding earthquakes-induced strong motions in dams (Chiu and Huang 1992; Huang and Chiu 1995, 1999), more studies are necessary. In addition, reservoir-induced seismicity (Simpson 1986) must be taken into account. Of course, there are alternative viewpoints. Mead (1982) indicated that the possibility of reservoir-induced earthquakes is very limited and probably should not be considered except for extremely large and deep reservoirs. Nevertheless, the largest documented induced earthquake with a magnitude of 6.5 occurred at Koyna Reservoir, which is small, with a dam height of $85 \mathrm{~m}$ above the river bed and a reservoir volume of $2.8 \mathrm{~km}^{3}$, in India (Gupta and Rastogi 1976). That event caused 200 deaths and 1500 injuries. Although the Feitsui dam is a moderate reservoir, long-term injection of water into the cracks and fissures of wall rocks underneath it could cause micro- or small events. Such events could potentially produce some damage to the dam. Therefore, installation of a local dense seismic array for long-term monitoring of micro- and small events below the Feitsui dam is necessary.

\section{Tatun Volcano Group}

There is a long debate concerning the issue of the TVG being extinct or not. Song et al. (2000) assume that the TVG can be re-active. Lin et al. (2005) stressed that they recorded several volcano-seismic signals such as tornillos, monochromatic events, and spasmodic bursts, which have often been observed in active volcanoes worldwide. This implies that these events are associated with direct or indirect interaction between hydrothermal or magmatic fluids and solid rocks in the upper crust. Whatever the case maybe, remnant geothermal activity is still able to generate events of magnitude 3 or more, which are usually shallow and capable of causing damage. It is noted that there are two nuclear plants operating near the volcanoes. If a volcano is not extinct, small and moderate earthquakes occur before eruption. Regardless of the volcanoes potential to erupt, small events in areas of high geothermal activity can be triggered by large distant 
earthquakes. This can be seen in the occurrence of small events in the geyser geothermal area of northern California and the Yellow Stone National Park in Wyoming. In these regions geothermal activity was remotely triggered by the 1992 M7 Landers earthquake of southern California (Hill et al. 1993). Of course, the issue of whether or not small events in the TVG could be triggered by large earthquakes is still an open question. Nevertheless, we still need to pay attention to possible events in the TVG caused by the abovementioned reasons as there are a large number of people living in the area. This is evidenced by the M5.3 earthquake of 3 July 1988 beneath the TVG that resulted in 16 injuries and small-scale damage and landslides.

Acknowledgements The author would like to express thanks to Prof. K. L. Wen (Associate Editor) and four reviewers for valuable comments and suggestions. Prof. L. S. Teng (NTU) allowed me to use his geology map of northern Taiwan. Drs. K. C. Chen and W. G. Huang (IES), and Dr. M. W. Huang (NCDR) assisted me to prepare the figures. This study was sponsored by Academia Sinica (Taipei) under Grant No. AS-94-TP-A08.

\section{REFERENCES}

Aki, K., 1967: Scaling law of seismic spectrum. J. Geophys. Res., 72, 1217-1231.

Astaneh, A., 1989: Preliminary report on the seismological and engineering aspects of the October 17, 1989 Santa Cruz (Loma Prieta) earthquake. Rept. No. UCB/ EERC-89/14, Earthquake Engin. Res. Center, UC Berkeley, Cal, USA.

Bilham, R., 1988: Earthquakes and urban growth. Nature, 336, 625-626.

Bonilla, M. G., 1977: Summary of Quarternary faulting and elevation changes in Taiwan. Mem. Geol. Soc. China, 2, 43-46.

Boore, D. M. and W. B. Joyner, 1997: Site amplifications for generic rock sites. Bull. Seismol. Soc. Am., 87, 327-341.

Boore, D. M., L. Seeking, and W. B. Joyner, 1989: Peak acceleration from the 17 October 1989 Loma Prieta earthquake. Seismol. Res. Lett., 60, 151-166.

Brune, J. N., 1970: Tectonic stress and spectra of seismic shear waves from earthquakes. J. Geophys. Res., 75, 4997-5009.

CGS (Central Geological Survey), 1999: Subsurface Geology and engineering environment of Taipei Basin. Special Pub., CGS, MOEA, ROC, 11, 406 pp.

Chan, Y. C., J. C. Lee, J. K. Liu, and D. Y. Cheng, 2005a: Surveys and monitoring of special geological hazards in the Taipei metropolitan area: High-precision airborne LIDAR mapping, topography, and analysis of structures. Open-File Rept., Central Geol. Surv.,
MOEA, ROC, 143 pp. (in Chinese)

Chan, Y. C., J. C. Lee, R. F. Chen, K. C. Chang, J. K. Liu, W. C. Hsu, J. C. Hu, W. S. Chen, C. C. Yang, Y. G. Chen, D. Y. Cheng, S. Tsao, and Y. C. Hsieh, 2005b: Airborne LIDAR mapping of the metropolitan Taipei area: Current status and progress. Proc. Symp. on Volcanic Activity and the Sanchiao Fault, Central Geol. Surv., MOEA, ROC, 87-101.

Chang, H. C., C. W. Lin, M. M. Chen, and S. T. Lu, 1998: An Introduction to the Active Faults of Taiwan, Explanatory Text of the Active Fault Map of Taiwan SCALE $1: 55000$. Central Geological Survey, MOEA, 103 pp. (in Chinese)

Chang, L. S. and Y. T. Yeh, 1983: The Q value of strong ground motions in Taiwan. Bull. Inst. Earth Sci., Acad. Sin., 3, 127-148.

Chen, K. C., 2003: Strong ground motion and damage in the Taipei basin from the Moho reflected seismic waves during the March 31, 2002, Hualien, Taiwan, earthquake. Geophys. Res. Lett., 30, doi: 10.1029/2003GL017193.

Chen, K. C., B. S. Huang, and W. G. Huang, 2005: Seismicity in the Taipei Basin and surroundings. Proc. Symp. on Volcanic Activity and the Sanchiao Fault, Central Geol. Surv., MOEA, ROC, 11-15.

Chen, K. J. and Y. H. Yeh, 1991: Gravity and microearthquakes studies in the Chinshan-Tanshui area, northern Taiwan. Terr. Atmos. Ocean. Sci., 2, 35-50.

Chen, K. J., Y. H. Yeh, H. Y. Yen, and C. H. Lin, 1995: Seismological studies in the Chinshan fault area. $J$. Geol. Soc. China, 38, 335-352.

Chen, K. J., Y. H. Yeh, and C. T. Shyu, 1996: Qp structure in the Taiwan area and its correlation to seismicity. Terr. Atmos. Ocean. Sci., 7, 409-429.

Chen, W. S., K. J. Lee, L. S. Lee, D. J. Ponti, C. Prentice, Y. G. Chen, H. C. Chang, and Y. H. Lee, 2004: Paleoseismology of the Chelungpu fault during the past 1900 years. Quat. Int., 115/116, 167-176.

Cheng, S. N. and Y. T. Yeh, 1989: Catalogue of Earthquakes in Taiwan from 1604 to 1988. Open-File Rept., Inst. Earth Sci., Acad. Sin., 255 pp. (in Chinese)

Chiu, H. C. and H. C. Huang, 1992: Effects of the canyon topography on ground motions at the Feitsui damsite. Bull. Seismol. Soc. Am., 82, 1646-1660.

Chou, J. T., 2004: Geological structure and characteristics of subsurface formations of the Taipei Basin in northern Taiwan. West. Pac. Earth Sci., 4, 1-24.

Fletcher, J. B. and K. L. Wen, 2005: Strong ground motion in the Taipei basin from the 1999 Chi-Chi, Taiwan, earthquake. Bull. Seismol. Soc. Am., 95, 1428-1446.

Gupta, H. K. and B. K. Rastogi, 1976: Dams and Earthquakes, Amsterdam, Elsevier, 299 pp.

Hill, D. P., P. A. Reasenber, A. Michael, W. J. Arabaz, G. Beroza, D. Brumbaugh, J. N. Brune, R. Castro, S. Davis, D. dePolo, W. Ellsworth, J. Gomberg, S. Harmsen, 
L. House, S. M. Jackson, M. J. S. Johnston, L. Jones, R. Keller, S. Malone, L. Munguia, S. Nada, J. C. Pechmann, A. Sanford, R. W. Simpson, R. B. Smith, M. Stark, M. Stickney, A. Vidal, S. Walter, V. Wong, and J. Zollweg, 1993: Seismicity remotely triggered by the magnitude 7.3 Landers, California, earthquake. Science, 260, 1617-1623.

Hsieh, C. H., C. M. Lin, and S. H. Hsieh, 1994: Seismic and well logging surveys in the Taipei Basin. Proc. Joint Symposium on Taiwan Quaternary and Invest. Subsurface Geology/Engineering Environ., Taipei Basin, 185-191.

Hsieh, C. H., S. H. Hsieh, and C. M. Lin, 1999: The investigation on Taipei Basin by shallow seismics and well loggings. Centr. Geol. Surv. Spec. Pub., 11, 253-272. (in Chinese)

Hsu, H., 1983a: Source materials on the history of natural disasters in Ching Taiwan. Hazards Mitigation S \& T Report, 72-01, 5-6.

Hsu, M. T., 1961: Seismicity of Taiwan (Formosa). Bull. Earthq. Res. Inst., Tokyo Univ., 39, 831-847.

Hsu, M. T., 1971: Seismicity of Taiwan and some related problem. Bull. Int. Inst. Seism. Earthq. Eng., Japan, 8, 41-160.

Hsu, M. T., 1980: Earthquake Catalog in Taiwan (from 1644 to 1979). Open-File Rept., Earthquake Engin. Center, Natl. Taiwan Univ., 77 pp. (in Chinese)

Hsu, M. T., 1983b: Estimation of earthquake magnitudes and seismic intensities of destructive earthquakes in the Ming and Ching Eras. Meteorol. Bull., CWB, 29, 1-18. (in Chinese)

Huang, C. C., Y. H. Lee, H. P. Liu, D. K. Keefer, and R. W. Jibson, 2001a: Influence of surface-normal ground acceleration on the initiation of the Jih-Feng-Erh-Shan landslide during the $1999 \mathrm{Chi}-\mathrm{Chi}$, Taiwan, earthquake. Bull. Seismol. Soc. Am., 91, 953-958.

Huang, H. C. and H. C. Chiu, 1995: The effect of canyon topography on strong ground motion at Feitsui damsite: Quantitative results. Earthq. Eng. Struc. Dyn., 24, 977-990.

Huang, H. C. and H. C. Chiu, 1999: Canyon topography effects on ground motion at Feitsui damsite. Soild Dyn. Earthq. Eng., 18, 87-99.

Huang, M. W. and J. H. Wang, 2002: Scaling of displacement spectra of near-fault seismograms of the 1999 Chi-Chi, Taiwan, earthquake. Geophys. Res. Lett., 29, doi: 10.1029/2001GL014021.

Huang, M. W., J. H. Wang, R. D. Hwang, and K. C. Chen, 2002: Estimates of source parameters of two large aftershocks of the 1999 Chi-Chi, Taiwan, earthquake in the Chia-Yi area. Terr. Atmos. Ocean. Sci., 13, 299-312.

Huang, M. W., J. H. Wang, H. H. Hsieh, K. L. Wen, and K. F. Ma, 2005: Frequency-dependent sites amplifications evaluated from well-logging data in cen- tral Taiwan. Geophys. Res. Lett., 32, L21302, doi: 10.1029/2005GL23527.

Huang, M. W., J. H. Wang, K. F. Ma, C. Y. Wang, J. H. Hung, and K. L. Wen, 2007a: Frequency-dependent site amplifications with $\mathrm{f} \geq 0.01 \mathrm{~Hz}$ evaluated from the velocity and density models in Central Taiwan. Bull. Seismol. Soc. Am., 97, 624-637.

Huang, M. W., J. H. Wang, H. H. Hsieh, K. L. Wen, K. F. Ma, and K. C. Chen, 2007b: Frequency-dependent sites amplifications evaluated from borehole data in the Taipei Basin. J. Seismol., submitted.

Huang, S., C. M. Rubin, Y. Chen, H. Liu, T. Su, T. Lai, and. C. Chiu, 2003, Prehistoric earthquakes along the Sanchiao fault, Taipei Basin, Northern Taiwan. AGU Fall Meeting.

Huang, W. G. and Y. T. Yeh, 1999: Characteristics of seismic source spectra from the Chia-Yi and Tai-Nan area of Taiwan. Terr. Atmos. Ocean. Sci., 10, 415-446.

Huang, W. G., J. H. Wang, B. S. Huang, K. C. Chen, T. M. Chang, R. D. Hwang, H. C. Chiu, and C. C. Tsai, 2001b: Estimates of source parameters for the Chi-Chi, Taiwan, earthquake, based on Brune's source model. Bull. Seismol. Soc. Am., 91, 1190-1198.

Hwang, L. J. and H. Kanomori, 1989: Teleseismic and strong motion source spectra from two earthquakes in Eastern Taiwan. Bull. Seismol. Soc. Am., 79, 935-944.

Hwang, R. D., G. K. Yu, and J. H. Wang, 2001a: Rupture directivity and source-process times of the September 20, 1999 Chi-Chi, Taiwan, earthquake estimated from Rayleigh-wave phase velocity. Earth Planets Space, 53, 1171-1176.

Hwang, R. D., J. H. Wang, B. S. Huang, K. C. Chen, W. G. Huang, T. M. Chang, H. C. Chiu, and C. C. Tsai, 2001b: Estimates of stress drop of the Chi-Chi, Taiwan, earthquake of September 20, 1999 from near-field seismograms. Bull. Seismol. Soc. Am., 91, 1158-1166.

Kim, K. H., J. M. Chiu, H. Kao, and Y. H. Yeh, 2004: A preliminary study of crustal structures in Taiwan region using receiver function analysis. Geophys. J. Int., 159, 146-164.

Kim, K. H., C. H. Chang, K. F. Ma, J. M. Chiu, and K. C. Chen, 2005: Modern seismic observations in the Tatun volcano region of northern Taiwan: Seismic/volcanic hazard adjacent to the Taipei Metropolitan area. Terr. Atmos. Ocean. Sci., 16, 579-594.

Konstantinou, K. I., C. H. Lin, and W. T. Liang, 2007: Seismicity characteristics of a potentially active Quaternary volcano: The Tatun Volcano Group, northern Taiwan. J. Volcanol. Geothermal Res., 160, 300-318, doi: 10.1016/j.jvolgeores.2006.09.009.

Kuo, K. W., T. C., Shin, and K. L. Wen, 1995: Taiwan strong motion instrumentation program (TSMIP) and preliminary analysis of site effects in Taipei basin from strong motion data. In: Cheng, F. Y. and M. S. Sheu 
(Eds.), Urban Disaster Mitigation: The Role of Engineering and Technology, Elsevier Science Ltd., 47-62.

Lee, C. T., 1993: Assessment of activity of the ChinshanShangjiao fault. Proc. Symp. Appl. Engineer. Geol. Tech. V, 153-172. (in Chinese)

Lee, C. T., C. T. Cheng, C. W. Liao, and Y. B. Tsai, 2001: Site classification of Taiwan free-field strong-motion stations. Bull. Seismol. Soc. Am., 91, 1283-1297.

Lee, J. F., 1996: A fault wedge structure - Concerning the formation of Taipei Basin. 30 th Intl. Geol. Congr., 1, Beijing, PRC, 4-14.

Lee, J. F., C. C. Lin, D. C. Lai, T. W. Su, Z. L. Chiu, and C. J. Zeng, 1999: The study of the formation of Taipei Basin. Centr. Geol. Surv. Spec. Pub., 11, 207-226. (in Chinese)

Lee, S. J., H. W. Chen, Q. Liu, D. Komatitsch, B. S. Huang, and J. Tromp, 2008: Three-dimensional simulations of seismic-wave propagation in the Taipei Basin with realistic topography based upon the spectral-element method. Bull. Seismol. Soc. Am., 98, 253-264.

Lermo, J. and F. J. Chávez-García, 1993: Site effect evaluation using spectral ratios with only one station. Bull. Seismol. Soc. Am., 83, 1574-1594.

Li, C. and H. C. Chiu, 1989: A simple method to estimate the seismic moment from seismograms. Proc. Geol. Soc. China, 32, 197-207.

Li, P. H., 1983: The strong earthquake recorders of 1900 to 1972: Re-analysis and occurrence time, spatial distributions study in Taiwan area. Open File Rept., Central Weather Bureau, 49 pp. (in Chinese)

Lin, C. H., 2002: Active continental subduction and crustal exhumation: the Taiwan orogeny. Terr. Nova, 14, 281-287.

Lin, C. H., 2005: Seismicity increase after the construction of the world's tallest building: An active blind fault beneath the Taipei 101. Geophys. Res. Lett., 32, L22313, doi: 10.1029/2005GL024223.

Lin, C. H., K. I. Konstantinou, W. T. Liang, H. C. Pu, Y. M. Lin, S. H. You, and Y. P. Huang, 2005: Preliminary analysis of volcano seismic signals recorded at the Tatun Volcano Group, northern Taiwan. Geophys. Res. Lett., 32, L10313, doi: 10.1029/2005GL022861.

Lin, C. S., 1957: Topography of Taiwan. Committee of Documentation, Taiwan Province, 303-314. (in Chinese)

Lin, C. T., 2001: Geological environment of the Taipei metropolitan area. Proc. Sympo. Geol. Hazards in the Taipei Metropolitan Area, 1.1-1.99. (in Chinese)

Liu, K. S., T. C. Shin, and Y. B. Tsai, 1999: A free-field strong motion Network in Taiwan: TSMIP. Terr. Atmos. Ocean. Sci., 10, 31-50.

Ma, K. F., J. H. Wang, and D. Zhao, 1996: Three-dimensional seismic velocity structure of the crustal and uppermost mantle beneath Taiwan. J. Phys. Earth, 44,
85-105.

Ma, K. F., C. T. Lee, Y. B. Tsai, T. C. Shin, and J. Mori, 1999: The Chi-Chi, Taiwan, earthquake: Large surface displacements on an inland thrust fault. EOS, Trans., $A G U, \mathbf{8 0}, 605-611$.

Mead, R. B., 1982: The evidence for reservoir-induced macroearthquakes. Misc. Pap. S-73-1, US Army Corps Eng., Waterw. Exp. Stn., Vicksburg, Miss., 194 pp.

Miyamura, S., 1985: The Hsinchu-Taichung, Taiwan, earthquake of April 20, 1935. In: Wang, J. H. (Ed.), Proc. Seminar Commem. 50th Anniv. for Hsinchu-Taichung Earthquake of 1935, 18-44.

Page, R. A., J. Mori, E. A. Roeloffs, and E. S. Schweig, 1997: Earthquake Hazards Program, Five-Year Plane 1998-2002. USGS Open-File Rept. 98-143, 35 pp.

Rau, R. J. and F. T. Wu, 1995: Tomographic imaging of lithospheric structures under Taiwan. Earth Planet. Sci. Lett., 133, 517-532.

Reasenberg, P. A. and L. M. Jones, 1989: Earthquake hazard after a mainshock in California. Science, 243, 1173-1176.

SCEC (Southern California Earthquake Center), 2002: SCEC2 Proposal. University of Southern California.

Scholz, C. H., 1990: The Mechanics of Earthquakes and Faulting. Cambridge Univ. Press, 439 pp.

Seno, T., 1977: The instantaneous rotation vector of the Philippine Sea plate relative to the Eurasian plate. Tectonophysics, 42, 209-226.

Shieh, Y. T., 2000: The paleogeograph of the ancient Taipei lakebed in the Kangshi period. J. Geogr. Sci., 27, 85-95. (in Chinese)

Shih, R. C., 2001: Engineering geology of the Taipei metropolitan area: Depp seismic reflection project to detect the basement beneath the Kwangtu plain. Open-File Rept., Central Geol. Surv., MOEA, ROC, 73 pp. (in Chinese)

Shin, T. C., 1992: Some implications of Taiwan tectonic features from the data collected by the Central Weather Bureau Seismic Network. Meteorol. Bull., CWB, 38, 23-48. (in Chinese)

Shin, T. C., 1993: Progress summary of the Taiwan Strong Motion Instrumentation Program. Proc. of Symp. on Taiwan Strong Motion Instrumentation Program, 1-10. (in Chinese)

Shin, T. C. and T. L. Teng, 2001: An overview of the 1999 Chi-Chi, Taiwan, earthquake. Bull. Seismol. Soc. Am., 91, 914-929.

Shin, T. C. and J. S. Chang, 2005: Earthquake monitoring systems in Taiwan. In: Wang, J. H., C. Y. Wang, Q. C. Sung, T. C. Shin, S. B. Yu, C. F. Shieh, K. L. Wen, S. L. Chung, M. Lee, K. M. Kuo, and K. C. Chang (Eds.), The 921 Chi-Chi Great Earthquake, Office of InterMinistry S \& T Program for Earthquake and Activefault Research, NSC, 43-59. (in Chinese) 
Shyu, J. B. H., K. Sieh, Y. G. Chen, and C. S. Liu, 2005: Neotectonic architecture of Taiwan and its implications for future large earthquakes. J. Geophys. Res., 110, B08402, doi: 10.1029/2004JB003251.

Sibson, R. H., 1977: Fault rocks and fault mechanisms. $J$. Geol. Soc. London, 133, 191-213.

Simpson, D. W., 1986: Triggered earthquakes. Annu. Rev. Earth Planet. Sci., 14, 21-42.

Sokolov, V. Y. and W. Y. Jean, 2002: Ground motion characteristics in the Taipei basin from earthquakes of various locations. Struct. Eng., 17, 18-30. (in Chinese)

Sokolov, V. Y., C. H. Loh, and K. L. Wen, 2000a: Empirical model for estimating Fourier amplitude spectra of ground acceleration in Taiwan region. Earthq. Engin. Struct. Dyn., 29, 339-357.

Sokolov, V. Y., C. H. Loh, and K. L. Wen, 2000b: Empirical study of sediment-filled basin response: A case of Taipei city. Earthq. Spectra, 16, 681-707.

Sokolov, V. Y., C. H. Loh, and K. L. Wen, 2001: Empirical model for site and region-dependent ground-motion parameters in Taipei area. Earthq. Spectra, 17, 313-331.

Sokolov, V. Y., C. H. Loh, and K. L. Wen, 2002a: Comparison of the Taiwan Chi-Chi earthquake strong motion data and ground motion assessment based on spectral model from smaller earthquake in Taiwan. Bull. Seismol. Soc. Am., 92, 1855-1877.

Sokolov, V. Y., C. H. Loh, and K. L. Wen, 2002b: Evaluation of models for Fourier amplitude spectra for the Taiwan region. Soil Dyn. Earthq. Eng., 22, 718-730.

Sokolov, V. Y., C. H. Loh, and K. L. Wen, 2003: Evaluation of hard rock spectral models for the Taiwan region on the basis of the 1999 Chi-Chi earthquake data. Soil Dyn. Earthq. Eng., 23, 715-735.

Sokolov, V. Y., C. H. Loh, and K. L. Wen, 2004: Evaluation of generalized site response functions for typical soil classes (B, C, and D) in Taiwan. Earthq. Spectra, 20, 1279-1316.

Song, S. R., S. Tsao, and H. J. Ho, 2000: Characteristics of the Tatun volcanic eruption, north Taiwa: Implications for a cauldron formation and volcanic evolution. J. Geol. Soc. China, 43, 361-378.

Teng, L. S., 1996: Extension collapse of the northern Taiwan mountain belt. Geology, 24, 949-952.

Teng, L. S., S. C. Wang, C. B. Chang, C. Hsu, P. B. Yuan, and P. Y. Chen, 1994: Quaternary strata frame of the Taipei basin. Proc. Joint Symposium on Taiwan Quaternary (5) and on Investigation of Subsurface Geology/ Engineering Environment of Taipei Basin, 129-135.

Teng, L. S., P. B. Yuan, P. Y. Chen, C. H. Peng, T. C. Lai, L. Y. Fei, and H. J. Liu, 1999: Lithostratigraphy of Taipei Basin deposits. Centr. Geol. Surv. Spec. Pub., 11, 41-66.

Teng, L. S., C. T. Lee, C. H. Peng, W. F. Chen, and C. J. Chu, 2001: Origin and geological evolution of the Tai- pei Basin, Northern Taiwan. West. Pac. Earth Sci., 1, 115-142.

Tsai, C. C. P., 1997: Relationships of seismic source scaling in the Taiwan region. Terr. Atmos. Ocean. Sci., 8, 49-68.

Tsai, C. C. P., W. W. Wang, C. P. Lin, and C. H. Jiang, 1994: Analyses of source parameters in Taiwan. $M e$ teorol. Bull. CWB, 8-1, 81-120.

Tsai, Y. B., 1985: A study of disastrous earthquakes in Taiwan, 1683-1895. Bull. Inst. Earth Sci., Acad. Sin., 5, $1-44$.

Tsai, Y. B., H. B. Liaw, and C. C. Feng, 1973: A study of microearthquakes in the Taitun volcanic region in northern Taiwan. Ann. Rept. Inst. Phys., Acad. Sin., 239-250.

Tsai, Y. B., T. L. Teng, J. M. Chiu, and H. L. Liu, 1977: Tectonic implications of the seismicity in the Taiwan region. Mem. Geol. Soc. China, 2, 13-41.

Tzou, Y. H. and G. K. Yu, 1987: Subsurface structure of the Tatun volcano group area inferred from the gravity data. Bull. Geophys., Natl. Central Univ., 27/28, 45-60.

Wang, C. Y., 1988a: Calculations of $\mathrm{Q}_{\mathrm{s}}$ and $\mathrm{Q}_{\mathrm{p}}$ using the spectral ratio method in the Taiwan area. Proc. Geol. Soc. China, 31, 81-89.

Wang, C. Y. and T. C. Shin, 1998: Illustrating 100 years of Taiwan seismicity. Terr. Atmos. Ocean. Sci., 9, 589614.

Wang, C. Y. and C. T. Sun, 1999: Interpretation of seismic stratigraphy in the Taipei Basin. Centr. Geol. Surv. Spec. Pub., 11, 293-315.

Wang, C. Y. and Y. H. Lee, 2002: An investigation of the basin structure in Taipei City. Proc. 2002 APEC Symposium on Confronting Urban Earthquakes/Seismic Early Warning, Nov. 28 - 29, Taipei, Taiwan, 137148.

Wang, C. Y., W. C. Hsiao, and C. T. Sun, 1994: Reflection seismic stratigraphy in Taipei basin (I) - northwestern Taipei basin. J. Geol. Soc. China, 37, 69-95.

Wang, C. Y., Y. L. Tsai, and M. L. Ger, 1995: Reflection seismic stratigraphy in Taipei basin (II) - southwestern Taipei basin. J. Geol. Soc. China, 38, 141-172.

Wang, C. Y., Y. H. Lee, and H. C. Chang, 1996: P- and S-wave Structures of the Taipei Basin. Symp. Taipei Strong Motion Instrumentation Program (II), Central Weather Bureau, 171-177.

Wang, C. Y., C. L. Li, and H. C. Lee, 2004a: Constructing subsurface structures of the Chelungpu fault to investigate mechanisms leading to abnormally large ruptures during the 1999 Chi-Chi earthquake, Taiwan. Geophys. Res. Lett., 31, L02608, doi: 10.1029/2003GL018323.

Wang, C. Y., Y. H. Lee, M. L. Ger, and Y. L. Chen, 2004b: Investigating subsurface structures and $\mathrm{P}$ - and $\mathrm{S}$-wave velocities in the Taipei Basin. Terr. Atmos. Ocean. 
Sci., 14, 609-628.

Wang, C. Y., Y. H. Lee, and Y. Y. Hu, 2005: Re-evaluating an active fault in a major computer-manufacturing area in northern Taiwan using "1 sec" shallow reflection sensors. Geophys. Res. Lett., 32, L08313, doi: 10.1029/ 2004 GL022344.

Wang, J. C., J. H. Wang, C. F. Shieh, and Y. H. Yeh, 2008: Static stress transfer between the Chinshan and Sanchiao faults in the Taipei Metropolitan Area. Terr. Atmos. Ocean. Sci., submitted.

Wang, J. H., 1985: Seismic moments and magnitudes of 16 moderate Taiwan earthquakes. Proc. Geol. Soc. China, 28, 177-185.

Wang, J. H., 1988b: b values of shallow earthquakes in Taiwan. Bull. Seismol. Soc. Am., 78, 1243-1254.

Wang, J. H., 1989: The Taiwan Telemetered Seismographic Network. Phys. Earth Planet. Inter., 58, 9-18.

Wang, J. H., 1992: Magnitude scales and their relations for Taiwan earthquakes: A review. Terr. Atmos. Ocean. Sci., 3, 449-468.

Wang, J. H., 1993: Q values of Taiwan: A review. J. Geol. Soc. China, 36, 15-24.

Wang, J. H., 1998: Studies of earthquake seismology in Taiwan during the 1897-1996 period. J. Geol. Soc. China, 41, 291-336.

Wang, J. H., 2005: Earthquakes rupturing the Chelungpu fault in Taiwan are time-predictable. Geophys. Res. Lett., 32, L06316, doi: 10.1029/2004GL021884.

Wang, J. H., 2006: SAFE-Taipei: A program project of strong motions, active faults, and earthquakes in the Taipei metropolitan area. In: Chen, Y. T. (Ed.), Advances in Geosciences, Vol. 1, World Scientific, Singapore, 61-74.

Wang, J. H., 2008: Potential earthquakes rupturing the Chinshan and Shangjiao faults in the Taipei Metropolitan Area. Terr. Atmos. Ocean. Sci., 19, 205-212, doi: 10.3319/TAO.2008.19.3.205(T).

Wang, J. H. and K. S. Liu, 1990: Azimuthal variation of coda Q in northern Taiwan. Geophys. Res. Lett., 17, 1315-1318.

Wang, J. H. and H. C. Kuo, 1995: A catalogue of $M_{s} \geq 7$ Taiwan earthquakes (1900 - 1994). J. Geol. Soc. China, 38, 95-106.

Wang, J. H., Y. B. Tsai, and K. C. Chen, 1983: Some aspects of seismicity in Taiwan region. Bull. Inst. Earth Sci., Acad. Sin., 3, 87-104.

Wang, J. H., K. C. Chen, and T. Q. Lee, 1994: Depth distribution of shallow earthquakes in Taiwan. J. Geol. Soc. China, 37, 125-142.

Wang, J. H., M. W. Huang, and W. G. Huang, 2006: Aspects of $\mathrm{M} \geq 4$ earthquakes in the Taipei metropolitan area. West. Pac. Earth Sci., 6, 169-190.

Wang, K. L., S. L. Chung, C. H. Chen, R. Shinjo, T. F. Yang, and C. H. Chen, 1999: Post-collisional mag- matism around northern Taiwan and its relation with opening of the Okinawa trough. Tectonophysics, $\mathbf{3 0 8}$, 363-376.

Wang-Lee, C. M. and T. P. Lin, 1987: The geology and land subsidence of the Taipei Basin. Mem. Geol. Soc. China, 9, 447-464.

Wells, D. L. and K. J. Coppersmith, 1994: New empirical relationships among magnitude, rupture length, rupture width, and surface displacement. Bull. Seismol. Soc. Am., 84, 974-1002.

Wen, K. L., 2005: Strong ground motions. In: Wang, J. H., C. Y. Wang, Q. C. Sung, T. C. Shin, S. B. Yu, C. F. Shieh, K. L. Wen, S. L. Chung, M. Lee, K. M. Kuo, and K. C. Chang (Eds.), The 921 Chi-Chi Major Earthquake, Office of Inter-Ministry S \& T Program for Earthquake and Active-fault Research, NSC, 318-349. (in Chinese)

Wen, K. L. and H. Y. Peng, 1998: Site effect analysis in the Taipei Basin: Results from TSMIP network data. Terr. Atmos. Ocean. Sci., 9, 691-704.

Wen, K. L., L. Y. Fei, H. Y. Peng, and C. C. Liu, 1995a: Site effect analysis from the records of the Wuku downhole array. Terr. Atmos. Ocean. Sci., 6, 285-298.

Wen, K. L., H. Y. Peng, L. F. Liu, and T. C. Shin, 1995b: Basin effects analysis from a dense strong motion observation network. Earthq. Eng. Struct. Dyn., 24, 1069-1083.

Wen, K. L., H. Y. Peng, Y. B. Tsai, and K. C. Chen, 2001: Why $1 \mathrm{~g}$ was recorded at TCU129 site during the 1999 Chi-Chi, Taiwan earthquake? Bull. Seismol. Soc. Am., 91, 1255-1266.

Wen, K. L., Y. T. Yeh, C. C. Liu, H. Y. Peng, L. F. Liu, and C. F. Wen, 1999: Study of the basin effects on seismic waves. Centr. Geol. Surv. Spec. Pub., 11, 293-315.

WGCEP (Working Group on California Earthquake Probabilities), 1995: Seismic hazards in Southern California: Probable earthquakes, 1994 to 2024. Bull. Seismol. Soc. Am., 85, 379-439.

Wu, F. T., 1965: Subsurface geology of the Hsinchuang structure in the Taipei Basin. Petrol. Geol. Taiwan, 4, 271-282.

Wu, F. T., 1978: Recent tectonics of Taiwan. J. Phys. Earth, 2(Suppl.), S265-S299.

Wu, Y. M. and T. L. Teng, 2002: A virtual sub-network approach to earthquake early warning. Bull. Seismol. Soc. Am., 92, 2008-2018.

Wu, Y. M., T. C. Shin, C. C. Chen, Y. B. Tsai, W. H. K. Lee, and T. L. Teng, 1997: Taiwan rapid earthquake information release system. Seismol. Res. Lett., 68, 931-943.

Wu, Y. M., J. K. Chung, T. C. Shin, N. C. Hsiao, Y. B. Tsai, W. H. K. Lee, and T. L. Teng, 1999: Development of an integrated seismic early warning system in Taiwan. Terr. Atmos. Ocean. Sci., 10, 719-736. 
Wu, Y. M., W. H. K. Lee, C. C. Chen, T. C. Shin, T. L. Teng, and Y. B. Tsai, 2000: Performance of the Taiwan Rapid Earthquake Information Release System (RTD) during the 1999 Chi-Chi (Taiwan) earthquake. Seismol. Res. Lett., 71, 328-333.

Yang, C. H. and C. S. Chen, 1989: Application of the TEM method in the Chinshan fault area, Chinshan, Taiwan. Proc. Geol. Soc. China, 32, 369-381.

Yu, S. B., 2000: Geodetic surveys for active faults and sub- sidence. Open-file Rept., Central Geol. Suv., 89 pp. (in Chinese)

Yu, S. B., H. Y. Chen, and L. C. Kuo, 1997: Velocity field of GPS stations in the Taiwan area. Tectonophysics, 274, 41-59.

Zhang, F., 2004: Site response and attenuation analysis using strong motion and short-period data. Ph.D. Dissertation, Dept. Civil Struct. Environ. Eng., SUNYBuffalo, 278 pp. 